\title{
Purification and biochemical characterization of a novel thermostable protease from the oyster mushroom Pleurotus sajor-caju strain CTM10057 with industrial interest
}

Maroua Omrane Benmrad ${ }^{1}$, Sondes Mechri ${ }^{1}$, Nadia Zaraî Jaouadi ${ }^{1,2}$, Mouna Ben Elhoul ${ }^{1,2}$, Hatem Rekik ${ }^{1,2}$, Sami Sayadi ${ }^{3}$, Samir Bejar ${ }^{1,2}$, Nabil Kechaou ${ }^{4}$ and Bassem Jaouadi ${ }^{1,2^{*}}$

\begin{abstract}
Background: Proteases are hydrolytic enzymes that catalyze peptide linkage cleavage reactions at the level of proteins and peptides with different degrees of specificity. This group draws the attention of industry. More than one protease in three is a serine protease. Classically, they are active at neutral to alkaline $\mathrm{pH}$. The serine proteases are researched for industrial uses, especially detergents. They are the most commercially available enzyme group in the world market. Overall, fungi produced extracellular proteases, easily separated from mycelium by filtration.

Results: A new basidiomycete fungus CTM10057, a hyperproducer of a novel protease (10,500 U/mL), was identified as Pleurotus sajor-caju (oyster mushroom). The enzyme, called SPPS, was purified to homogeneity by heattreatment $\left(80^{\circ} \mathrm{C}\right.$ for $20 \mathrm{~min}$ ) followed by ammonium sulfate precipitation (35-55\%)-dialysis, then UNO Q-6 FPLC ion-exchange chromatography and finally HPLC-ZORBAX PSM 300 HPSEC gel filtration chromatography, and submitted to biochemical characterization assays. The molecular mass was estimated to be $65 \mathrm{kDa}$ by sodium dodecyl sulfate polyacrylamide gel electrophoresis (SDS-PAGE), Native-PAGE, casein-zymography, and size exclusion by HPLC. A high homology with mushroom proteases was displayed by the first 26 amino-acid residues of the $\mathrm{NH}_{2}$-terminal aminoacid sequence. Phenylmethanesulfonyl fluoride (PMSF) and diiodopropyl fluorophosphates (DFP) strongly inhibit SPPS, revealing that it is a member of the serine-proteases family. The $\mathrm{pH}$ and temperature optima were 9.5 and $70^{\circ} \mathrm{C}$, respectively. Interestingly, SPPS possesses the most elevated hydrolysis level and catalytic efficiency in comparison with SPTC, Flavourzyme $500 \mathrm{~L}$, and Thermolysin type X proteases. More remarkably, a high tolerance towards organic solvent tolerance was exhibited by SPPS, together with considerable detergent stability compared to the commercial proteases Thermolysin type $X$ and Flavourzyme $500 \mathrm{~L}$, respectively. Conclusions: This proves the excellent proprieties characterizing SPPS, making it a potential candidate for industrial applications especially detergent formulations.
\end{abstract}

Keywords: Protease, Oyster mushroom, Pleurotus sajor-caju, Organic solvent, Peptide synthesis, Detergent formulations

\footnotetext{
*Correspondence: bassem.jaouadi@cbs.rnrt.tn; biotechecozym@gmail.com

'Laboratory of Microbial Biotechnology and Engineering Enzymes (LMBEE),

Centre of Biotechnology of Sfax (CBS), University of Sfax, Road of Sidi

Mansour Km 6, P.O. Box 1177, 3018 Sfax, Tunisia

${ }^{2}$ Biotech ECOZYM Start-up, Business Incubator, Centre of Biotechnology of

Sfax (CBS), University of Sfax, Road of Sidi Mansour Km 6, P.O. Box 1177, 3018

Sfax, Tunisia

Full list of author information is available at the end of the article
}

(c) The Author(s). 2019 Open Access This article is distributed under the terms of the Creative Commons Attribution 4.0 International License (http://creativecommons.org/licenses/by/4.0/), which permits unrestricted use, distribution, and reproduction in any medium, provided you give appropriate credit to the original author(s) and the source, provide a link to the Creative Commons license, and indicate if changes were made. The Creative Commons Public Domain Dedication waiver (http://creativecommons.org/publicdomain/zero/1.0/) applies to the data made available in this article, unless otherwise stated. 


\section{Background}

Enzymes are natural catalysts, which are increasingly more required in various industrial fields and bioprocesses. Today, researchers focus on detecting new enzymes endowed with extremely satisfactory properties for commercial applications [1, 2]. Using enzymes in industrial process has a large number of advantages, namely their specificity and lower pressures, i.e. lower cost. Besides, they can be preserved for a long time. They are also biodegradable, therefore causing less environmental pollution. Global demand for industrial enzymes is expected to rise up to almost 7.1 billion dollars in 2018, www.FreedoniaGroup.com (Cleveland, USA). Compared to plant and animal enzymes, microbial enzymes are the most attractive ones to industrialists owing to their ease of production [3]. In fact, the microbial proteases production is beneficial thanks to their distinctive features such as short generation time, easy manipulation of microorganisms genes, and large availability in nature [1]. Besides, their preferred properties in biotechnology are widely approved. Proteases isolated from plant and animal do not receive industrial demand save for some uses. Around three quarts of industrial biocatalysts are hydrolyses $[4,5], 65 \%$ of them are proteases of the total industrial enzyme market $[6,7]$. The business applications of proteases are quickly growing thanks to the current technological advances. These hydrolyzes possess have original properties and substrate specificities [8]. They have been well-studied, being considered as the most attractive group [9]. The majority of the total sales $(89 \%)$ of protease are used in detergent formulation [10]. Historically, proteases were the first to be used in laundry detergents [2, 11, 12], about twothird share of this industry $[13,14]$. Thanks to these enzymes, detergent industries have made considerable progress $[11,13]$. It is noteworthy that protease is a hydrolytic biocatalyst which catalyzes the interruption of protein polymers $[9,12,15,16]$. It contributes significantly in the metabolism of almost all organisms [4]. Besides, bio-additives improving the efficiency and the performance of laundry detergents are receiving increasing demands. In fact, a large number of researches are focusing on the isolation and purification of alkaline proteases for detergence purpose. Although industrial applications resort to bacterial proteases, the process of cell elimination is expensive, thus their use is restricted [17]. It is noteworthy that bacteria produce the majority of proteases of microbial origin. In fact, Bacillus genus produces neutral and alkaline proteases. The excellent properties of basidiomycetes' proteases pave the way for further study. Although the 3D structural and functional proprieties of basidiomycetes proteases occurred more than 30 years ago in scientific research, the variety and complexity of xylotrophic basidiomycetes enzymes action has resulted in interesting studies. In this respect, our researches are focused on fungi protease thanks to their easy cell separation. The study of micromycetes proteases has recently shed lights on the specific characteristics of enzymes [5, 18]. Moreover, basidiomycota are a secret treasure proteolytic variety [19]. Several species of strains including fungi (viz. Aspergillus flavus, Aspergillus clavatus, Aspergillus melleu, Aspergillus niger, Fusarium graminarum, Chrysosporium keratinophilum, Penicillium griseofulvin, Penicillium chrysogenum, Scedosporium apiosermum, and Trametes cingulata) and bacteria (viz. Bacillus licheniformis, Bacillus amyloliquefaciens, Bacillus pumilus, Bacillus safensis, Bacillus firmus, Bacillus alcalophilus, Bacillus proteolyticus, Bacillus subtilis, and Bacillus thuringiensis) are described as foodstuffs proteases [6, 12, 20, 21]. However, the fungi protease origin, Penicillium and Aspergillus are widely studied, as a greater species and can produce different proteases types, such as Aspergillus oryzae. In fact, mushroom species have been proven to possess various biological effects. For centuries, mushrooms have been used as food and food materials, as well as being topics of study in many fields, namely medicine and cosmetics. Oyster mushrooms, particularly, represent a type of specialty mushroom that is much prized around the world and most popularly in the United States. Indeed, mushrooms are a source of protein, vitamins $\mathrm{C}$ and $\mathrm{B}$, and minerals, and mainly endowed with a very low fat content [22]. Many bioactive molecules, including protease, have been isolated from superior fungi. More than twenty proteases have been isolated from fungi species [23]. Moreover, the study of basidiomycota's proteases is still limited. Thus, the study of new Pleurotus proteases is a biotechnology area that necessitates to be discovered. The Pleurotus species are extremely valued in cooking thanks to their refined flavor and they have also been examined in different bioactive molecules such as antitumor, hypocholesterolemic, anti-inflammatory antiviral, antioxidant, antibiotic, antidiabetic, antitumor, immunomodulatory, antihyperlipidemic, and hepatoprotective compounds etc. [1]. Numerous researches have demonstrated the fibrinolytic activity of edible mushrooms, including Flammulina velutipes, Pleurotus ostreatus, Grifola frondosa, Tricholoma saponaceum, and Armillaria mellea [23]. The genus Pleurotus is known for laccase production. This is linked to the ligninolytic metabolism with the presence of proteases. In addition to laccase production, this genus is known for the hydrolytic enzymes production by Pleurotus spp. that have been designated, resulting in these properties of this genus for future research [1].

The study of saprophytic basidiomycetes proteases has led to the isolation of different classes of proteases [19]. As white rot fungi, the genus Pleurotus has ligninolytic 
[24] and proteolytic $[1,5,19]$ enzymes. A few studies have investigated the proteolytic enzymes isolated from Pleurotus spp. as reported. This microorganism is a white rot fungi and the second crucial group of fungi cultivated in life, with more than 30 species [1]. It is the most produced edible mushroom, withstanding any temperature. It was found in tropical and subtropical regions and can grow artificially with no difficulties. This genus can be cultivated at any substrate and temperature. In fact, its easy cultivation is performed by means of cheap nutriments. Besides, it is characterized by excellent adaptation [5, 25], and therefore, a high yield of production.

In this study, a novel alkaline and detergent-stable protease, called SPPS, from the fungus Pleurotus sajor-caju strain CTM10057, was purified to homogeneity and its enzymatic characteristics were examined. Moreover, the enzymatic performance evaluation of the SPPS was compared with other used proteases. This present work provides valuable information on biochemical characteristics of SPPS from the oyster mushroom.

\section{Methods}

Substrates, chemicals, and used comparative proteases

All the chemicals and substrates used in this study were reagent position, unless specified otherwise. General reagents were obtained from commercial suppliers. The SPTC enzyme is a fungi protease from Trametes cingulata CTM10101 [26]. The Flavourzyme $500 \mathrm{~L}$ is a commercial fungal proteolytic enzyme from Aspergillus oryzae supplied by Novozymes A/S (Bagsvaerd. Denmark). The Thermolysin type $\mathrm{X}$ is a commercial protease from Geobacillus stearothermophilus purchased from Sigma Aldrich Inc., Fluka, Chemical Co. (St. Louis, MO, USA).

\section{Isolation and growth culture conditions of protease-} producing white-rot-fungi and enzyme production Fruiting bodies of a wild Pleurotus and Shiitake were collected from different biotope sites, from the symptomatic wood of the camphor trees Quercus faginea (L.) at the El Feïdja National Park (Aïn Draham, Jendouba, Tunisia) to isolate protease-producing fungi. Mycelium pure cultures of the Pleurotus P10 (designated as CTM10057) were obtained in Petri dishes, containing potato dextrose agar (PDA) medium at $28 \pm 2{ }^{\circ} \mathrm{C}$ and $\mathrm{pH}$ 6.0. The plates were then incubated for $7 \mathrm{~d}$ at $28 \pm$ $2{ }^{\circ} \mathrm{C}$. To avoid bacterial growth, the plates were supplemented with chloramphenicol $25 \mu \mathrm{g} / \mathrm{mL}$. The proteaseproducing fungal strain was tested onto skimmed milk agar plates containing $(\mathrm{g} / \mathrm{L})$ : peptone, 5 ; yeast extract, 3; skimmed milk $250 \mathrm{~mL}$; and bacteriological agar, 20 at $\mathrm{pH}$ 7.4. The protease-producing strain was propagated on PDA plates at $28 \pm 2{ }^{\circ} \mathrm{C}$, and the inoculates were prepared from 6-day-old colonies by flooding with $10 \mathrm{~mL}$ of sterile distilled water and scraping off the agar plates. 2 $\mathrm{mL}$ of homogenized mycelium were used for inoculation of 1000-mL Erlenmeyer flask with baffles, containing $100 \mathrm{~mL}$ of culture medium. This basal medium incorporates a complete potato dextrose broth (PDB) liquid culture medium supplemented with $(\mathrm{g} / \mathrm{L}): 15$ lentil flour; 3 yeast extract; 10 glucose; $1 \mathrm{KH}_{2} \mathrm{PO}_{4} ; 1 \mathrm{~K}_{2} \mathrm{HPO}_{4}$ at $\mathrm{pH}$ 5.6. Cultures were incubated for $3 \mathrm{~d}$ at $28^{\circ} \mathrm{C}$ on a rotary shaker with a shaking speed of $180 \mathrm{rpm}$. Afterwards, the culture broths were centrifuged at $11000 \times g$ for $30 \mathrm{~min}$ to remove mycelia and medium debris. The cell-free supernatant was designated as crude enzyme.

\section{PCR amplification and ITS of 185 rDNA gene sequencing and molecular phylogenetic investigation}

The genomic DNA of the isolate fungal strain CTM10057 was extracted from freeze-dried mycelia according to CTAB method as investigated previously by $\mathrm{Li}$ [27]. The gene encoding ITS region of rDNA was amplified by the fungi identification PCR kit by means of universal primers ITS1 and ITS4 as described elsewhere [13]. The PCR product was placed into the PCR2.1 vector by means of a pCR-Blunt ended cloning kit (GE Healthcare/Amersham Biosciences Corp., Piscataway, NJ, USA). The nucleotide sequences of both strands pertaining to the cloned ITS rDNA gene sequence were sequenced in both directions via universal primers (U-19 and T7) using the automated DNA sequence ABI PRISM ${ }^{\circ}$ 3100-Avant Genetic Analyzer (Applied Biosystems, Foster City, CA, USA). The nucleotide sequence alignment was conducted several times, using the BioEdit (v 7.0.2) software. The analyses of phylogenetic and molecular evolutionary were carried out using Molecular Evolutionary Genetics Analysis (v 4.1) program.

\section{Determination of protease activity}

The SPPS activity was measured spectrophotometrically at $660 \mathrm{~nm}$ using casein as substrate [28] at $70^{\circ} \mathrm{C}$ and $100 \mathrm{mM}$ glycine- $\mathrm{NaOH}$ buffer added with $2 \mathrm{mM} \mathrm{CaCl}$ at pH 9.5 (i.e., Buffer A), under the standard assay conditions described previously [26].

The SPPS activity, in detergent solution, was measured at $450 \mathrm{~nm}$ using $N, N$-dimethylated casein as substrate at $40^{\circ} \mathrm{C}$ and $\mathrm{pH} 9$ as reported elsewhere [29].

\section{SPPS purification procedure}

To remove microbial cells, five hundred $\mathrm{mL}$ of a $72-\mathrm{h}$ culture of Pleurotus sajor-caju strain CTM10057 were centrifuged. The supernatant containing extracellular protease was used as the crude enzyme preparation and submitted to the following purification steps. First, the filtrate was incubated for $20 \mathrm{~min}$ at $80^{\circ} \mathrm{C}$ and insoluble material was removed by centrifugation at $11000 \times g$ for $20 \mathrm{~min}$. The ammonium sulfate was added to clear supernatant to reach $35 \%$ saturation, then centrifuged at 
$11000 \times g$ for $30 \mathrm{~min}$. The saturation of the obtained supernatant was done up to $55 \%$ with solid $(\mathrm{NH} 4)_{2} \mathrm{SO}_{4}$, re-centrifuged, re-suspended in a minimal volume of 50 mM PIPES at pH 6.1 (i.e., Buffer B), and dialyzed overnight against repeated changes of the same buffer. The sample, thus, obtained was deposited on a UNO Q-6 column $(12 \mathrm{~mm} \times 53 \mathrm{~mm})$, using FPLC system, previously equilibrated with buffer $B$. The proteins were eluted with the same buffer, containing an increasing concentration of $\mathrm{NaCl}$ of 0 to $500 \mathrm{mM}$ at a rate of 0.5 $\mathrm{mL} / \mathrm{min}$. Fractions of each peak were collected manually and analyzed by measuring absorbance at $280 \mathrm{~nm}$ and the proteolytic activity on casein. Pooled fractions, containing protease activity, were further resolved by HPLC system using ZORBAX PSM 300 HPSEC $(6.2 \mathrm{~mm} \times 250$ $\mathrm{mm}$ ), Agilent Laboratories, pre-equilibrated with $25 \mathrm{mM}$ HEPES buffer at pH 7.5, were supplemented with $2 \mathrm{mM}$ $\mathrm{CaCl}_{2}$ (i.e., Buffer C). Protein was separated by molecular weight at a flow rate of $0.5 \mathrm{~mL} / \mathrm{min}$ with buffer $\mathrm{C}$ and the protease activity was detected using a UV spectrophotometric detector at $280 \mathrm{~nm}$.

\section{Proteins measurement, electrophoresis, and analytical methods}

Protein concentration was measured as reported by Bradford [30], using BSA as reference. Previously reported by Laemmli [31], the subunit molecular weight of the purified SPPS enzyme was evaluated by SDS-PAGE under reducing conditions, using $12 \%$ separating gel ( $\mathrm{pH} 8.8$ ) and 5\% stacking gel ( $\mathrm{pH}$ 6.8). The Native-PAGE or non-reducing conditions of the purified SPPS was performed using $12 \%$ resolving gel (stacking gel was omitted) in Tris-glycine buffer $(\mathrm{pH} 8.5)$ at $4{ }^{\circ} \mathrm{C}$. The molecular weight of the purified SPPS protein was determined in comparison with standard protein markers and also confirmed by size exclusion HPLC, using ZORBAX PSM 300 HPSEC (Agilent Technologies, Lawrence, Kansas, MO, USA), pre-equilibrated with the buffer $C$. The protein bands were visualized with Coomassie Brilliant Blue R-250 (Bio-Rad Laboratories, Inc., Hercules, CA, USA) staining. Substrate-PAGE, or casein zymography staining, was performed by incorporating azo-casein into the separating gel before polymerization as detailed by Jaouadi et al. [32]. The gels were rinsed twice for $30 \mathrm{~min}$ in Triton X-100 (2.5\%), after electrophoresis, in order to remove the SDS. The occurrence of clearance zone around the protein band on the blue background elucidated the SPPS protease activity.

\section{Edman degradation for amino-acid sequencing}

To sequence $\mathrm{NH}_{2}$-terminal, the bands of purified SPPS enzyme were cut from SDS gels and transferred to a ProBlott membrane (Applied Biosystems, Foster City, CA, USA). Accordingly, in order to perform such analysis, we used automated Edman's degradation at the Faculty of Science of Sfax (FSS), University of Sfax, by means of a protein sequencer (Applied Biosystems Protein sequencer ABI Procise 492/610A).

\section{Biochemical characterization of the purified SPPS enzyme Effects of inhibitors and metallic ions on enzyme stability}

The effects of some inhibitors and various divalent metallic ions on protease stability were examined by means of pre-incubating the purified SPPS enzyme for $1 \mathrm{~h}$ at $40{ }^{\circ} \mathrm{C}$, in the presence of each inhibitor or metallic ions, in order to characterize the SPPS-owned class. Performing enzyme assays required standard assay conditions.

\section{Influence of $\mathrm{pH}$ on the activity and stability of SPPS}

The influence of $\mathrm{pH}$ was carried out with casein at $10 \mathrm{~g} /$ $\mathrm{L}$ as a substrate. Protease activities were studied over a $\mathrm{pH}$ range $[2.0-13.0]$ at $70^{\circ} \mathrm{C}$. For the measurement of $\mathrm{pH}$ stability, the purified SPPS enzyme was preincubated in buffers at different $\mathrm{pH}$ in the range of 2.013.0 for $24 \mathrm{~h}$ at $40{ }^{\circ} \mathrm{C}$. Aliquots were withdrawn periodically and the residual proteolytic activities were measured as aforementioned.

\section{Effects of temperature on the enzyme activity and stability}

With respect to proteolysis activity, its optimum temperature was determined via performing SPPS at $\mathrm{pH}$ 9.5 at different temperatures from 40 to $100{ }^{\circ} \mathrm{C}$, with and without $2 \mathrm{mM} \mathrm{CaCl}_{2}$. At a pH of 9.5, the thermostability was determined by incubating SPPS at 80, 90, and $100{ }^{\circ} \mathrm{C}$ for $12 \mathrm{~h}$ of incubation with and without $2 \mathrm{mM}$ $\mathrm{CaCl}_{2}$. Aliquots were withdrawn at desired time intervals to test the remaining activity under standard conditions. Considered as control (100\%), the non-heated SPPS was left at room temperature. Half-life times of the purified SPPS protease were determined after incubation at 80 , 90, and $100{ }^{\circ} \mathrm{C}$ for $12 \mathrm{~h}$.

\section{Effect of various polyol(s) and /or calcium on SPPS thermostability}

The effect of variety of polyols, with concentration of $100 \mathrm{mg} / \mathrm{mL}$, on SPPS thermostability was carried out by its incubation at $90^{\circ} \mathrm{C}$ for $1 \mathrm{~h}$ with and without different polyols. The combination of sorbitol $(100 \mathrm{mg} / \mathrm{mL})$ and calcium $(2 \mathrm{mM})$ on the thermostability of SPPS enzyme was monitored at $90^{\circ} \mathrm{C}$ for $12 \mathrm{~h}$. Protease assays were carried out under the standard experimental assay conditions.

Kinetic study of the SPPS, SPTC, Flavourzyme ${ }^{\circledR} 500 \mathrm{~L}$, and Thermolysin type $\mathrm{X}$ enzymes

Substrate specificities profile

The substrate profile specificity of SPPS was determined using natural and modified protein substrates as well as 
esters substrates. Enzymatic activities were determined on each substrate based on standard conditions, previously described elsewhere [33, 34].

\section{Kinetic measurements}

The kinetic constants for protease activity were determined by performing casein as substrate at different concentrations, ranging from 0.10 to $50 \mathrm{mg} / \mathrm{mL}$ for 20 $\min$. The $\mathrm{pH}$ and temperature values used in the kinetic study were adjusted to the optimum conditions for each enzyme (SPPS, pH 9.5 and $70^{\circ} \mathrm{C}$; SPTC, pH 9.0 and $60^{\circ} \mathrm{C}$; Flavourzyme $500 \mathrm{~L}$, pH 11.0 and $60^{\circ} \mathrm{C}$; and Thermolysin type $\mathrm{X}, \mathrm{pH} 8.0$ and $70^{\circ} \mathrm{C}$ ). The purified enzymes used were SPPS; SPTC; Flavourzyme ${ }^{\circ} 500 \mathrm{~L}$, and Thermolysin, at a final concentration of proteins $1.5 \mathrm{mg} / \mathrm{mL}$ using natural (casein) as specific substrates for all proteases. Each assay was carried out in triplicate, and Lineweaver-Burk plots were used in order to rate kinetic parameters. The Hyper32 v.1.0. software was used to calculate Kinetic constants, Michaelis-Menten constant $\left(K_{\mathrm{m}}\right)$, and maximal reaction velocity $\left(V_{\max }\right)$ values.

\section{Performance evaluation of the purified SPPS, SPTC, Flavourzyme ${ }^{\oplus} 500 \mathrm{~L}$, and Thermolysin type $\mathrm{X}$ enzymes Determination of hydrolysis degree with casein}

Casein hydrolysis was carried out at $70^{\circ} \mathrm{C}$ and $\mathrm{pH} 9.5$ for SPPS; at $60^{\circ} \mathrm{C}$ and $\mathrm{pH} 9.0$ for SPTC; at $70^{\circ} \mathrm{C}$ and pH 8.0 for Thermolysin type $\mathrm{X}$; and at $60^{\circ} \mathrm{C}$ and $\mathrm{pH} 11.0$ for Flavourzyme $500 \mathrm{~L}$. So, an amount of $5 \mathrm{~g}$ of casein was dissolved in $100 \mathrm{~mL}$ of $100 \mathrm{mM}$ buffer per used enzyme and then treated with $500 \mathrm{U}$ of the purified enzymes (SPPS, SPTC, Flavourzyme $500 \mathrm{~L}$, and Thermolysin type $\mathrm{X})$. For each case, the degree of hydrolysis (DH) was calculated based on the amount of base $(\mathrm{NaOH})$ added so that the $\mathrm{pH}$ remains constant during hydrolysis [35] as previously reported by Zaraî Jaouadi [34]. The DH is defined as the percentage of peptide bonds cleaved according to the total number of peptide bonds, i.e. it is the ratio of free amino-acids to those in peptide linkage and the relative size of the peptide fragments [36]. By totally decomposing the protein into its constituent elements, this degree of hydrolysis is estimated to be $100 \%$. Since enzymes are specific biocatalysts, no enzyme alone is capable of hydrolyzing each peptide bond of a protein up to $100 \% \mathrm{DH}$. Indeed, the $\mathrm{DH}$ of an enzyme provides us with an idea of its functionality. Hydrolysis helped to keep the $\mathrm{pH}$ titrimetrically constant by using the $\mathrm{pH}$ Stat (Metrohm 718 Stat Titrino, Herisau, Switzerland) set at the desired $\mathrm{pH}$ value of each enzyme via constantly adding $5 \mathrm{~N}$ of $\mathrm{NaOH}$ (caustic soda) $[35,37]$.

\section{Effects of organic-solvents on protease stability}

Various organic solvents, with different $\log \mathrm{P}_{\text {ow }}$ values at $50 \%(\mathrm{v} / \mathrm{v})$, were tested by shaking at 150 strokes per min and $37^{\circ} \mathrm{C}$ for $72 \mathrm{~h}$ to evaluate their effects on SPPS and Thermolysin type $\mathrm{X}$ protease stabilities. The polarity or hydrophobicity of an organic solvent was quantified by a parameter termed "log $\mathrm{P}_{\text {ow }}$ " value. Generally, organic solvents, using low $\log \mathrm{P}_{\text {ow }}$ values, show more biotoxicity and result in the inhibition of the biocatalyst compared with high $\log \mathrm{P}_{\mathrm{ow}}$ solvents [38]. The relative and residual caseinolytic activities were assayed under each assay condition at $70^{\circ} \mathrm{C}$ and $\mathrm{pH} 9.5$ (for SPPS) and at $60^{\circ} \mathrm{C}$ and $\mathrm{pH} 8.0$ (for Thermolysin type X). Devoid of any organic solvent, the activity of SPPS was taken as $100 \%$.

\section{Compatibility of SPPS enzyme with some commercial detergents}

The stability of the alkaline proteases (SPPS, Flavourzyme $^{\circ} 500 \mathrm{~L}$, and SPTC) in the presence of miscellaneous laundry detergents was examined by incubating enzymes $(500 \mathrm{U} / \mathrm{mL})$ for $1 \mathrm{~h}$ at $40^{\circ} \mathrm{C}$ with various common detergent preparations $(7 \mathrm{mg} / \mathrm{mL})$, and the residual activities were determined. Prior to the addition of each purified enzyme, the endogenous enzymes contained in used detergents were deactivated by incubating the diluted detergents at $65^{\circ} \mathrm{C}$ for $1 \mathrm{~h}$. Under similar incubation conditions, the enzyme activity of a control (devoid of any detergent) was taken as $100 \%$.

\section{Washing performance evaluation of SPPS enzyme}

The application of the proteases SPPS and Flavourzyme ${ }^{\circ}$ $500 \mathrm{~L}$ at $500 \mathrm{U} / \mathrm{mL}$ as a detergent bio-additive in Dixan detergent $(7 \mathrm{mg} / \mathrm{mL})$ were studied on white cotton cloth pieces stained with blood and evaluated as already detailed by the authors [26].

\section{Culture collection depository number and nucleotide sequence accession number}

The fungal culture of P10 isolate was deposited in the " Collection Tunisienne de Microorganismes (CTM) » at the Service of Culture Collection Maintenance of the Centre of Biotechnology of Sfax (Sfax, Tunisia) under the authentic culture collection number: $\mathrm{CTM}<\mathrm{TUN}>$ : 10057 (designated as CTM10057). The data reported in this work for the nucleotide sequences of the 18S rDNA (750 bp) gene were deposited in the GenBank/ENA/ EMBL databases under accession number: MH806376.

\section{Results}

\section{Screening of alkaline protease-producing strains}

The new basidiomycete fungus, Pleurotus P10, was newly isolated from the symptomatic wood of the camphor trees Quercus faginea (L.) at the El Feïdja National Park, Aïn Draham (Jendouba, Tunisia). It was registered in the CTM-CBS under the authentic culture number: "CTM10057" and was retained, for further and advanced study, as the highest protease producer fungal strain on 
skimmed milk agar after $24 \mathrm{~h}$ (with diameter of clear zone/ diameter of colony growth $>3 \mathrm{~mm}$ ) and on PDB liquid medium after $72 \mathrm{~h}$ (Fig. 1) (with protease activity = $10,500 \mathrm{U} / \mathrm{mL})$ at $28 \pm 2{ }^{\circ} \mathrm{C}$.

\section{Identification and molecular phylogeny of the microorganism}

In order to identify CTM10057 strain, the internal transcribed spacer region of $18 \mathrm{~S}$ rDNA (750 bp) was amplified, cloned in PCR2.1 vector and sequenced. The ITS nucleotide sequence was analyzed with the GenBank database using BLAST program and showed 99 and $98 \%$ homology with ITS of Pleurotus sajor-caju MUCL:40167 (accession no.: JN645075) and Trametes marianna BJFC12714 (accession no.: KC848334) strains, respectively. The phylogenetic tree was established by the neighbor-joining method (data not shown). The multiple alignment and phylogenetic tree revealed that CTM10057 strain is Pleurotus sajor-caju (accession no.: MH806376).

\section{Purification of SPPS enzyme}

The SPPS enzyme was purified from the culture supernatant according to the procedure described in the Methods section. The supernatant was obtained by the centrifugation of a 72-h old culture of the Pleurotus sajor-caju strain CTM10057 (Fig. 1) using broth (500 $\mathrm{mL}$ ) as a crude enzyme solution. The protein elution profile obtained at the final purification step indicated that the protease was eluted at $110-160 \mathrm{mM} \mathrm{NaCl}$ (Fig. 2a). Fractions corresponding protease activity were loaded in HPLC column.

The results of the purification procedure are summarized in Table 1. SPPS purified enzyme preparation contained about $15 \%$ of the total activity of the crude and had a specific activity of 79,000 U/mg (Table 1).

\section{Molecular weight determination of SPPS enzyme}

To analyze the homogeneity and molecular weight of the purified SPPS enzyme, Native-PAGE and SDS-PAGE were performed. As shown in Fig. 2b, the molecular mass of the SPPS was almost $65 \mathrm{kDa}$, as assessed by Native-PAGE. Moreover, the SPPS preparation was a homogeneous pure enzyme with high purity confirmed by a symmetrical peak with retention time $\left(\mathrm{R}_{\mathrm{t}}\right)$ of $11.6 \mathrm{~min}$, matching with protein of $\sim 65 \mathrm{kDa}$ (Fig. 2c) reached after native condition in HPLC chromatography (Fig. 2c). Under reducing conditions (SDS-PAGE), a unique monomeric protein band estimated to $65 \mathrm{kDa}$ was obtained for the purified SPPS enzyme (Fig. 2d) corresponding to that determined by gel filtration. Purity of the SPPS protease was also evaluated by zymography. The zymogram activity staining confirms the presence of a clear zone of protease activity for the purified sample and total cell extract co-migrating with proteins, having molecular masses of $65 \mathrm{kDa}$ (Fig. 2e).

These observations strongly suggested that SPPS was a monomeric protein comparable to those previously reported for other fungi proteases [25, 26, 33, 39].

\section{$\mathrm{NH}_{2}$-terminal amino-acid sequence determination of SPPS enzyme}

The sequence of the first $26 \mathrm{NH}_{2}$-terminal amino-acid residues of SPPS from the Pleurotus sajor-caju strain CTM10057 was determined as: GPEDPALPPDSESTHVITGVEKLHAQ. It showed uniformity, thus indicating that it was isolated in a pure form. This sequence was submitted to comparisons with existing protein sequences in the GenBank non-redundant protein

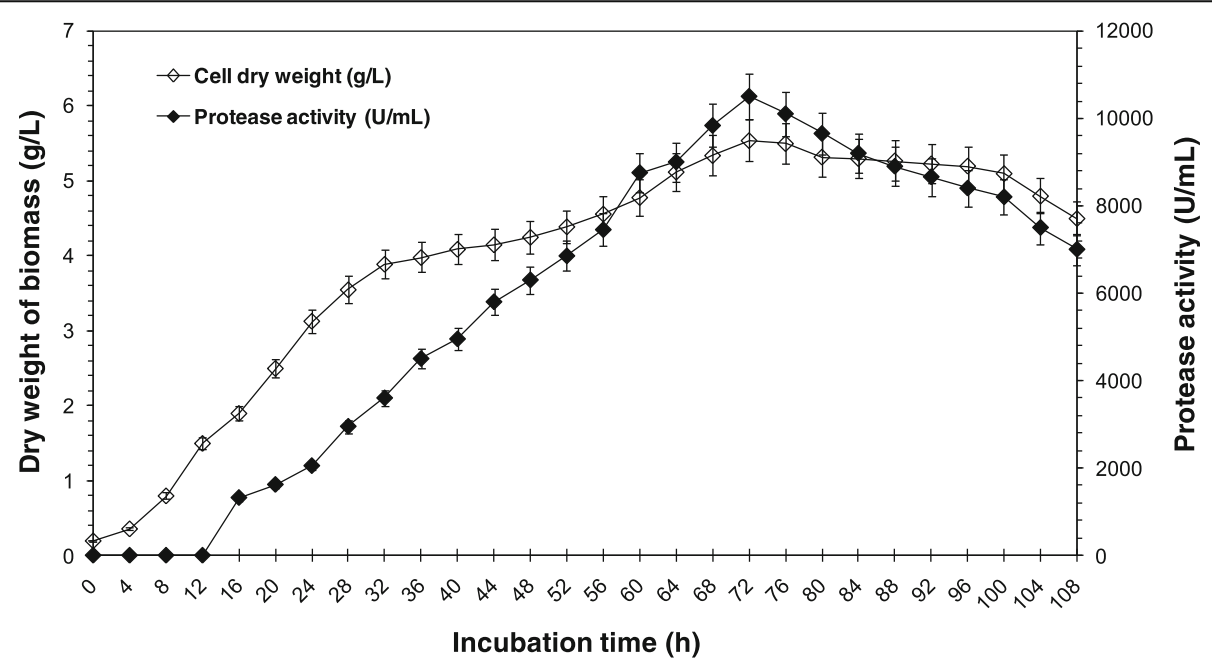

Fig. 1 Time course of Pleurotus sajor-caju strain CTM10057 biomass (dry weight of mycelia) ( $)$ ) and protease activity (production) ( $\bullet$ ) on optimized culture medium. Cell growth was performed by measuring the dry matter. Protease activity was determined in culture filtrates obtained after removal of cells by centrifugation, as described in Methods section. Each point represents the mean $(n=3) \pm$ standard deviation 


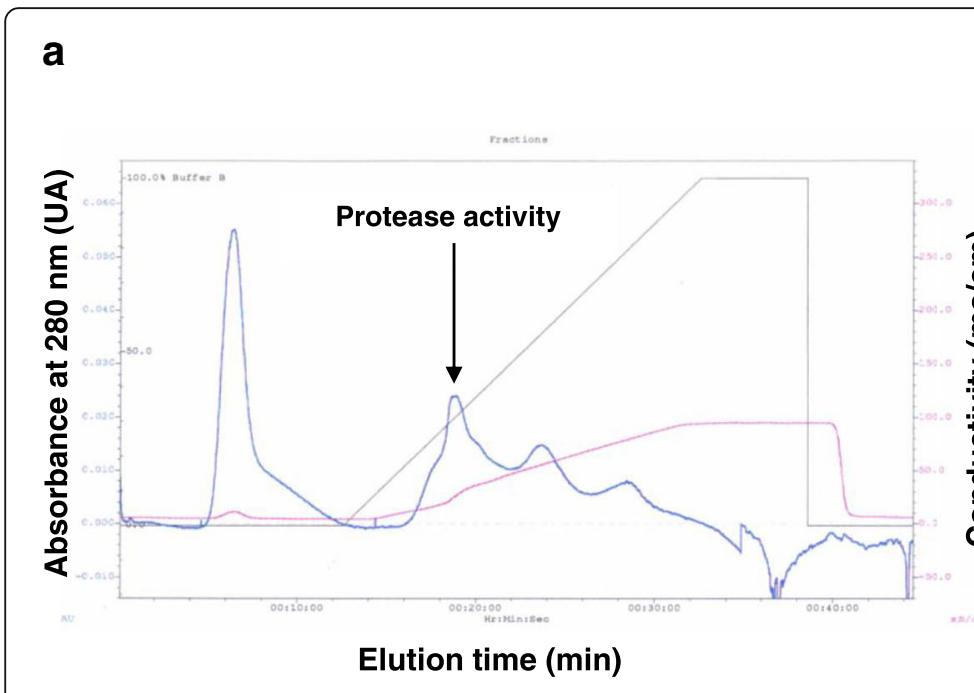

b

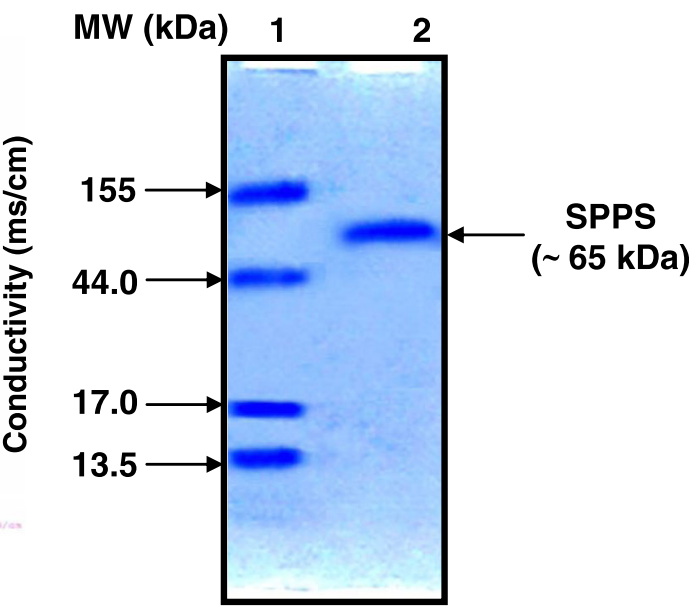

C

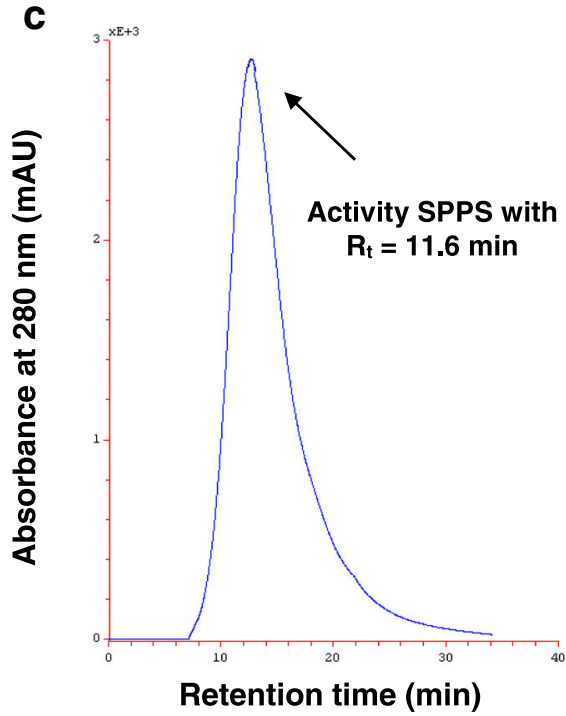

d

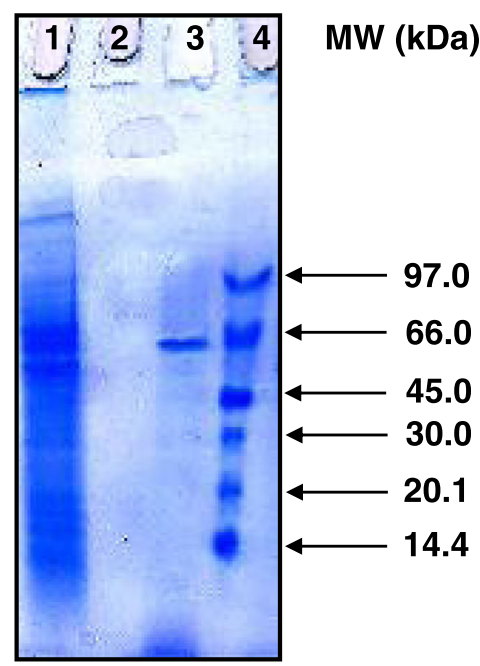

e

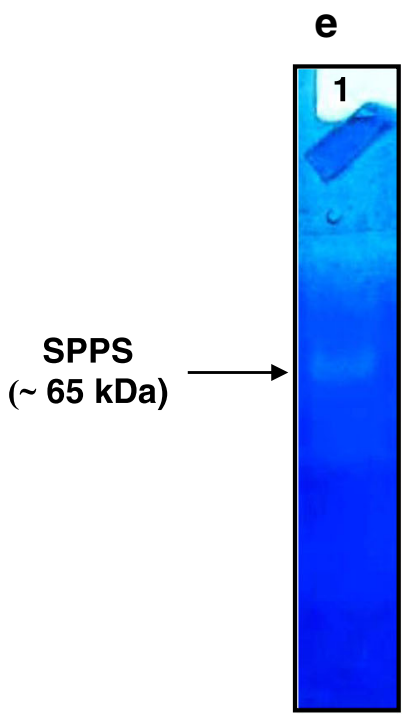

Fig. 2 Purification and identification of the protease SPPS from Pleurotus sajor-caju strain CTM 10057. a Chromatography profile of the partial protease purification on FPLC system using UNO Q-6. The column (12 mm $\times 53 \mathrm{~mm}$ ) (Bio-Rad Laboratories, USA) was equilibrated with buffer C. The adsorbed material was eluted with a linear $\mathrm{NaCl}$ gradient $(0$ to $500 \mathrm{mM}$ in buffer $\mathrm{C}$ at a flow rate of $30 \mathrm{~mL} / \mathrm{h}$, as described in Methods section. $\mathbf{b}$ The assessment of homogeneity and molecular weight analysis of purified SPPS protein on Native-PAGE, Lane 1, protein markers (molecular masses in kDa). Lane 2, purified SPPS enzyme from Pleurotus sajor-caju strain CTM $10057(30 \mu \mathrm{g})$. c Chromatography profile of the purified protease SPPS on HPLC system using ZORBAX PSM 300 HPSEC. The column $(6.2 \mathrm{~mm} \times 250 \mathrm{~mm}$ ) (Agilent Technologies, Lawrence, Kansas, MO, USA) was equilibrated with buffer $C$ and native protein markers of $670,158,44,17$, and $13.5 \mathrm{kDa}$, show a single peak of $65 \mathrm{kDa}$, approximately. Proteins were separated by isocratic elution at a flow rate of $30 \mathrm{~mL} / \mathrm{h}$ with buffer $\mathrm{C}$ and detected using a UV-VIS

Spectrophotometric detector (Knauer, Berlin, Germany) at $280 \mathrm{~nm}$. The pure SPPS enzyme, with retention time ( $\left.R_{t}\right)$ of 11.6 min, contains protease activity. d SDS-PAGE 12\% of the purified protease. Lane 1, Total cell extract. Lane 2, Empty. Lane 3, Purified SPPS (30 $\mu$ g) obtained after HPLCZORBAX PSM 300 HPSEC chromatography at $R_{t}=11.6$ min. Lane 4: Amersham LMW protein marker (GE Healthcare Europe GmbH, Freiburg, Germany). e Zymogram caseinolytic activity staining of the purified protease SPPS $(30 \mu \mathrm{g})$

database and the Swiss-Prot database, using the BLASTP and tBlastn search programs (Table 2). The alignment of the $\mathrm{NH}_{2}$-terminal amino-acid shows that this sequence has homology with the subtilisin-like proteases; or this group of subtilisin-like proteases is found in bacteria, mammals, insects, and in some yeasts. This protease class exhibits significant homology with the protease of basidomycetes fungi, which consist of 300 to 400 aminoacid residues and do not have disulfide bridges as well as being characterized by the absence of cysteine and cystine residues. They are involved in various functions depending on the species, having in most cases nutritive 
Table 1 Flow sheet purification of SPPS from Pleurotus sajor-caju strain CTM10057

\begin{tabular}{llllll}
\hline Purification step $^{\text {a }}$ & Total activity (units) ${ }^{\text {b }} \times 10^{4}$ & Total protein (mg) $)^{\text {b.c }}$ & $\begin{array}{l}\text { Specific activity } \\
\text { (U/mg of protein) }{ }^{\text {b }}\end{array}$ & $\begin{array}{l}\text { Activity recovery rate } \\
(\%)\end{array}$ & $\begin{array}{l}\text { Purification factor } \\
\text { (fold) }\end{array}$ \\
\hline Crude extract & $525 \pm 13$ & $590 \pm 14$ & 8823 & 100 & 1 \\
Heat treatment $\left(20\right.$ min at $80^{\circ} \mathrm{C}$ ) & $430 \pm 10$ & $240 \pm 6$ & 17,917 & 82 & 2 \\
$\left(\mathrm{NH}_{4}\right)_{2} \mathrm{SO}_{4}$ fractionation $(35-55 \%)$-dialysis & $375 \pm 9$ & $160 \pm 4$ & 23,437 & 71.4 & 3 \\
FPLC (UNO Q-6) & $152 \pm 3$ & $40 \pm 1$ & 38,000 & 28.5 & 4.3 \\
HPLC (ZORBAX PSM 300 HPSEC) & $79 \pm 2$ & $10 \pm 0.5$ & 79,000 & 15 & 9
\end{tabular}

${ }^{a}$ Experiments were conducted three times and \pm standard errors are reported

${ }^{b}$ One unit $(U)$ of protease activity was defined as the amount of enzyme required to release $1 \mu \mathrm{g}$ tyrosine per minute under the experimental conditions used

c Amounts of protein were estimated by the method of Bradford [30]

functions. The effect of calcium as a stabilizer was demonstrated in some cases. It appears that the $\mathrm{Ca}^{2+}$ ion binds and gives the enzyme a more or less rigid structure, thus decreasing auto-digestion. The $\mathrm{NH}_{2}$-terminal sequence displayed a medium to significant similarity $(64-90 \%)$ compared to that of fungi serine proteases. Table 2 represents the $\mathrm{NH}_{2}$-terminal sequence of SPPS, which was compared to other closely related proteolytic sequences, noted to share greatest homology with fungal proteolytic enzymes, especially those from Pleurotus ostreatus strain ATCC $^{\circ}$ MYA-2306 ${ }^{\text {tm }}$ (90\% similarity with SPPS). The latter contains one modified amino-acid. The Glu3 residue in SPPS was substituted by Asp3. Besides, SPPS showed 85, 79, 75, and 64\% similarities with proteases from Schizopora paradoxa strain KUC8140, Phlebia centrifuga strain FBCC195, Phanerochaete chrysosporium strain S1, and Metarhizium anisopliae strain ARSEF 549, respectively. The $\mathrm{NH}_{2}$-terminal amino-acid of SPPS sequence differed from protease PR1C from Metarhizium anisopliae strain ARSEF 549 (64\% similarity with SPPS) by fifteen aminoacid residues at positions G1L, P2S, E3S, D4R, A7D, L8D, P8G, P9A, S11I, E12F, T14P, I17M, E21K, and K22L. These results and the comparison with the closest enzymes indicated that SPPS proteolytic enzyme is a new member of the serine protease from fungal strains family.

\section{Biochemical proprieties of SPPS enzyme Influence of enzyme inhibitor and metal ions}

In order to determine the nature of SPPS enzyme, the effect of several enzyme inhibitors, (chelating agent and a specific group reagent) [7] on enzyme stability was investigated (Table 3). Trypsin-like and chymotrypsin competitive reagents did not have any influence on the stability of the purified SPPS. However, SPPS was thoroughly inhibited by the serine protease inhibitors, indicating that this enzyme belongs to that subclass. Metallo-enzyme inhibitors EDTA and EGTA sparsely affect the SPPS stability. EDTA at $1 \mathrm{mM}$ and EGTA at 2 mM inhibited SPPS only by 91 and $80 \%$ of its activity, respectively. The relative stability of this enzyme in the presence of EDTA and EGTA is beneficial and auxiliary for use as detergent bio-additive, since detergents formulation contain high portion of chelating agents, which function as water softeners and further facilitate the proteinacious stain removal. Other metallic ions were also assayed for their effects on SPPS activity (Table 3). This fungi protease enzyme is totally activated by $\mathrm{Ca}^{2+}, \mathrm{Mg}^{2+}$, and $\mathrm{Fe}^{2+}$ but strongly inhibited by $\mathrm{Cd}^{2+}, \mathrm{Ni}^{2+}$, and $\mathrm{Hg}^{2+}$ (2 mM).

\section{Effects of $\mathrm{pH}$ on protease activity and stability}

According to the results presented in Fig. 3a, SPPS possesses an optimum activity at $\mathrm{pH} 9.5$. This fungi protease keeps 60 and $71 \%$ of its original activity at $\mathrm{pH} 5.0$ and 11.0, respectively. In order to study $\mathrm{pH}$ stability, SPPS was incubated in buffers at various $\mathrm{pH}$ values. The $\mathrm{pH}$ stability profile revealed that SPPS was highly stable in the $\mathrm{pH}$ range of $6.0-11.0$. The half-life times of SPPS at pH6.0, 7.0, 8.0, 9.0, 10.0, and 11.0 were $22,20,18,16,10$, and $6 \mathrm{~h}$, respectively (Fig. 3b). SPPS is an alkaline protease stable in

Table 2 Alignment of the $\mathrm{NH}_{2}$-terminal amino-acid sequence of the purified SPPS from Pleurotus sajor-caju strain CTM10057 with the sequences of other fungal proteases

\begin{tabular}{|c|c|c|c|}
\hline Enzyme & Origin & $\mathrm{NH}_{2}$-terminal amino-acid ${ }^{\mathrm{a}, \mathrm{b}}$ & Identity (\%) \\
\hline SPPS (this work) & Pleurotus sajor-caju strain CTM10057 & GPEDPALPPDSESTHVITGVEKLHAQ & - \\
\hline PoSl & Pleurotus ostreatus strain ATCC ${ }^{\circledast}$ MYA-2306 ${ }^{\text {TM }}$ & GPDDPALPPD & 90 \\
\hline PA_PoS1 & Schizopora paradoxa strain KUC8140 & GPTDPAIPPDSESTHVLTGV & 85 \\
\hline VPR & Phlebia centrifuga strain FBCC195 & DDPAIPPDTESTHVLTGVDKLHAQ & 79 \\
\hline PCSI & Phanerochaete chrysosporium strain S1 & GKSDPAVPADTESTH & 75 \\
\hline PR1C & Metarhizium anisopliae strain ARSEF 549 & LSSRADDGADIFSPHVMTQVKL & 64 \\
\hline
\end{tabular}

amino-acid sequences for comparison were obtained using the program BLASTP (NCBI, NIH, USA) database with default parameters

${ }^{\mathrm{b}}$ Residues not identical with SPPS protease from Pleurotus sajor-caju strain CTM10057 are indicated in black box 
Table 3 Effects of various inhibitors, reducing agents, and metallic ions on SPPS enzyme stability. Protease activity measured in the absence of any inhibitor or reducing agent was taken as control (100\%). The non-treated and dialyzed enzyme was considered as $100 \%$ for metallic ion assay. Residual activity was measured at $\mathrm{pH} 9.5$ at $70{ }^{\circ} \mathrm{C}$

\begin{tabular}{|c|c|c|c|c|}
\hline Reagent & & Specificity/origin & Concentration & $\begin{array}{l}\text { Relative protease stability } \\
(\%)^{\mathrm{a}}\end{array}$ \\
\hline \multirow{19}{*}{$\begin{array}{l}\text { Inhibitor/reducing } \\
\text { agents }\end{array}$} & Control & & - & $100 \pm 2.5$ \\
\hline & PMSF or DFP & Serine protease specific inhibitors & $5 \mathrm{mM}$ & $0 \pm 0.0$ \\
\hline & Benzamidine & Competitive inhibitor of serine proteases & $10 \mathrm{mM}$ & $103 \pm 2.6$ \\
\hline & Aprotinin & & $5 \mathrm{mM}$ & $101 \pm 2.5$ \\
\hline & SBTI & Soybean trypsin inhibitor & $3 \mathrm{mg} / \mathrm{mL}$ & $101 \pm 2.5$ \\
\hline & TPCK & Chymotrypsin specific inhibitor & $1 \mathrm{mM}$ & $94 \pm 2.2$ \\
\hline & TLCK & Trypsin-like specific inhibitor & $1 \mathrm{mM}$ & $102 \pm 2.5$ \\
\hline & DTNB & Cysteine or thiol-containing protease inhibitors & $5 \mathrm{mM}$ & $41 \pm 0.8$ \\
\hline & NEM & & $5 \mathrm{mM}$ & $74 \pm 1.8$ \\
\hline & MIA & & $10 \mathrm{mM}$ & $97 \pm 2.4$ \\
\hline & EPNP & & $2 \mathrm{mM}$ & $87 \pm 2.1$ \\
\hline & lodoacetamide & & $50 \mu \mathrm{g} / \mathrm{mL}$ & $65 \pm 1.4$ \\
\hline & $\beta-M E$ & Thiol reducing agent for cleaving protein disulfide & $1 \mathrm{mM}$ & $66 \pm 1.6$ \\
\hline & LD-DTT & & $50 \mu \mathrm{M}$ & $61 \pm 1.5$ \\
\hline & EDTA & Specific metallo-protease inhibitors & $1 \mathrm{mM}$ & $91 \pm 2.2$ \\
\hline & EGTA & & $2 \mathrm{mM}$ & $80 \pm 2.1$ \\
\hline & $\begin{array}{l}\text { 1,10-Phenanthroline } \\
\text { monohydrate }\end{array}$ & & $10 \mathrm{mM}$ & $102 \pm 2.5$ \\
\hline & Leupeptine & Acid protease specific inhibitors & $10 \mu \mathrm{g} / \mathrm{mL}$ & $101 \pm 2.5$ \\
\hline & Pepstatine A & & $10 \mathrm{mM}$ & $104 \pm 2.7$ \\
\hline \multirow[t]{10}{*}{ Metallic ions } & Control & & - & $100 \pm 2.5$ \\
\hline & $\mathrm{Ca}^{2+}$ & $\mathrm{CaCl}_{2}$ & $2 \mathrm{mM}$ & $270 \pm 6.0$ \\
\hline & $\mathrm{Mg}^{2+}$ & $\mathrm{MgCl}_{2}$ & $2 \mathrm{mM}$ & $180 \pm 3.8$ \\
\hline & $\mathrm{Fe}^{2+}$ & $\mathrm{FeCl}_{2}$ & $2 \mathrm{mM}$ & $145 \pm 3.4$ \\
\hline & $\mathrm{Cu}^{2+}$ & $\mathrm{CuCl}_{2}$ & $2 \mathrm{mM}$ & $99 \pm 2.5$ \\
\hline & $\mathrm{Mn}^{2+}$ & $\mathrm{MnCl}_{2}$ & $2 \mathrm{mM}$ & $109 \pm 2.6$ \\
\hline & $\mathrm{Co}^{2+}$ & $\mathrm{CoCl}_{2}$ & $2 \mathrm{mM}$ & $61 \pm 1.2$ \\
\hline & $\mathrm{Ba}^{2+}$ & $\mathrm{BaCl}_{2}$ & $2 \mathrm{mM}$ & $75 \pm 1.8$ \\
\hline & $\mathrm{Zn}^{2+}$ & $\mathrm{ZnCl}_{2}$ & $2 \mathrm{mM}$ & $40 \pm 0.8$ \\
\hline & $\mathrm{Hg}^{2+}$ or $\mathrm{Cd}^{2+}$ or $\mathrm{Ni}^{2+}$ & $\mathrm{HgCl}_{2}, \mathrm{CdCl}_{2}$, or $\mathrm{NiCl}_{2}$ & $2 \mathrm{mM}$ & $0 \pm 0.0$ \\
\hline
\end{tabular}

a Values represent means of three independent replicates, and \pm standard errors are reported

SBTI soybean trypsin inhibitor, TPCK Na-p-tosyl-L-phenylalanine chloromethyl ketone, TLCK Na-p-tosyl-L-lysine chloromethyl ketone, DTNB 5,5'-dithio-bis-2-nitro benzoic acid, NEM N-ethylmalemide, MIA monoiodoacetic acid, EPNP 1.2-epoxy-3-(p-nitrophenoloxy) propane, $\beta$-ME $\beta$-mercaptoethanol, LD-DTT LD-dithiothreitol

alkaline solution. This propriety is solicited in protease and used as bio-additive in detergent formulations.

\section{Effects of temperature on protease activity and stability}

The optimum temperature for SPPS at $\mathrm{pH} 9.5$ was $60^{\circ} \mathrm{C}$ devoid of $\mathrm{CaCl}_{2}$ and $70{ }^{\circ} \mathrm{C}$ using $2 \mathrm{mM} \mathrm{Ca}^{2+}$ as shown in Fig. 3c. The half-life times of SPPS in the absence of any additive were 8,3 , and $1 \mathrm{~h}$ at 80,90 , and $100^{\circ} \mathrm{C}$, respectively. The addition of different concentrations of $\mathrm{CaCl}_{2}$ (1 to $10 \mathrm{mM}$ ) improved the thermostability of SPPS. The maximal thermostability was reached with $2 \mathrm{mM} \mathrm{Ca}^{2+}$. As shown in Fig. 3d, the half-life times of SPPS at 80, 90 , and $100{ }^{\circ} \mathrm{C}$ increased to 10,5 , and $3 \mathrm{~h}$ in the presence $2 \mathrm{mM} \mathrm{CaCl}_{2}$. Compared to other proteases isolated from this genus announced in the review of Inácio et al. [1], SPPS has the highest optimum temperature and highest $\mathrm{pH}$. This fungus protease is an alkaline protease acid tolerant and it is highly stable and active at high temperature and $\mathrm{pH}$. SPPS is an acid resistant protease. This enzyme can have a biotechnology perspective in food applications. The high activity and stability 


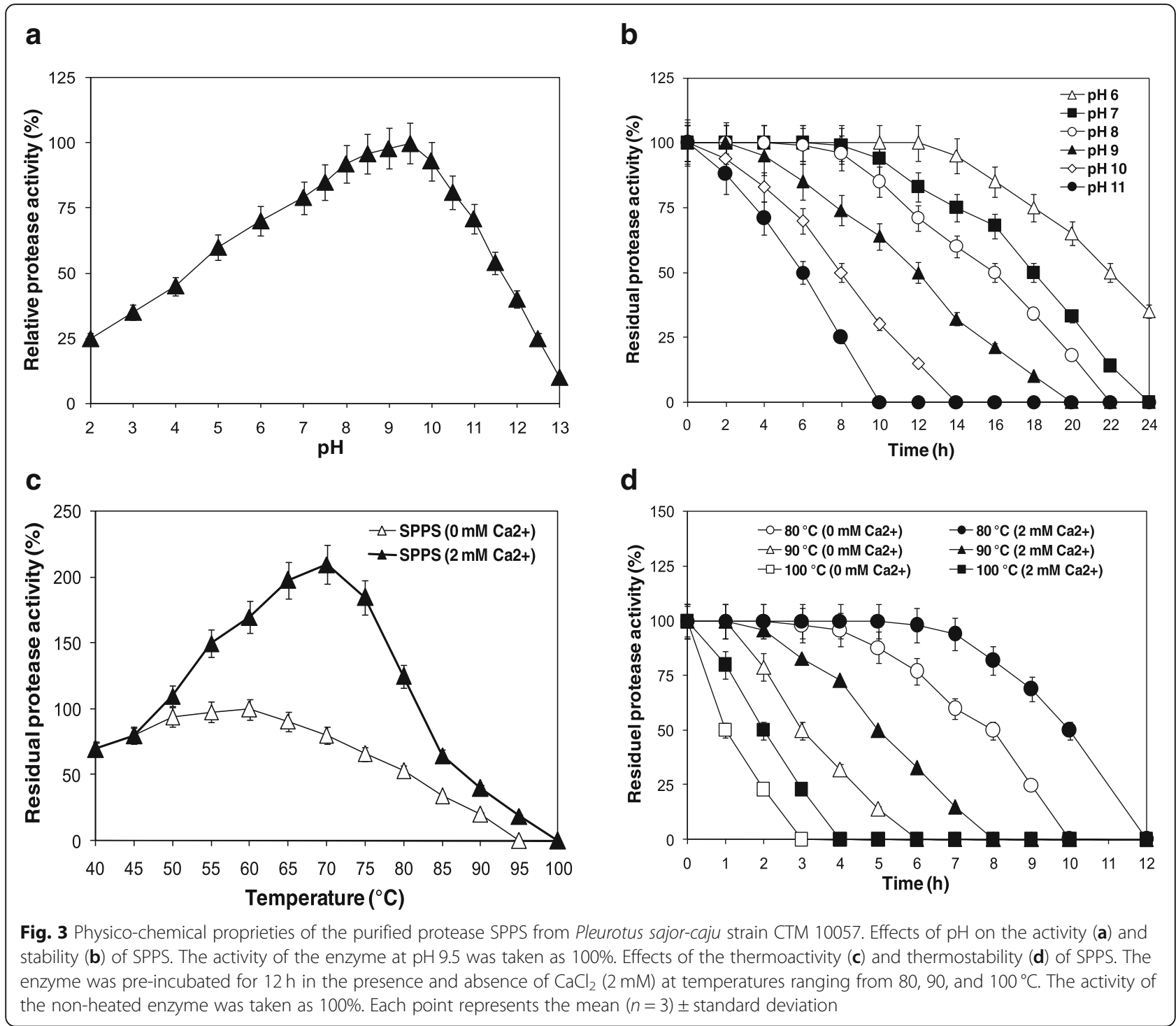

exhibited by SPPS at high $\mathrm{pH}$ solutions is, in fact, a very important attribute that provides further support for its potential strong candidacy for future application in detergent formulations since laundry detergents generally operate at a pH ranging from 7.0 to11.0 [6].

\section{Effect of some polyols on the thermostability of SPPS}

As detailed earlier, the modification of the microenvironment of enzymes via the addition of polyols in aqueous solutions generally improves its thermostability [40]. In the respect to determine the stabilizing effect, several polyols on SPPS enzyme thermal stability was investigated at $90^{\circ} \mathrm{C}$ for $1 \mathrm{~h}$ (Fig. 3a). Data demonstrated that sorbitol was the best additive used. The combination effect of sorbitol and $\mathrm{CaCl}_{2}$ was also assayed at $90^{\circ} \mathrm{C}$ for $12 \mathrm{~h}$. The results displayed in Fig. $4 \mathrm{~b}$ show that the half time is $9 \mathrm{~h}$ (in the presence of sorbitol and $\mathrm{CaCl}_{2}$ compared to $3 \mathrm{~h}$ in the absence of the two additives) (Fig. 4b). Thus, the combination effect of sorbitol and $\mathrm{CaCl}_{2}$ enhance the SPPS thermal stability. This improvement of SPPS thermostability in the presence of calcium and polyol is presumably attributed to the strengthening of interactions inside protein molecules and the binding of $\mathrm{Ca}^{2+}$ and sorbitol to the autolysis site.

Kinetic study of the SPPS, SPTC, Flavourzyme ${ }^{\circledR} 500 \mathrm{~L}$, and Thermolysin type $X$ enzymes

\section{Substrate specificities}

The substrate specificity of proteases is often attributed to the amino-acid residues preceding the peptide bond they hydrolyze. The relative hydrolysis rates of various substrates were investigated to elucidate the amino-acid preference/substrate specificity of SPPS (Table 4). The specificity of cleavage to ester is well detailed in 
a

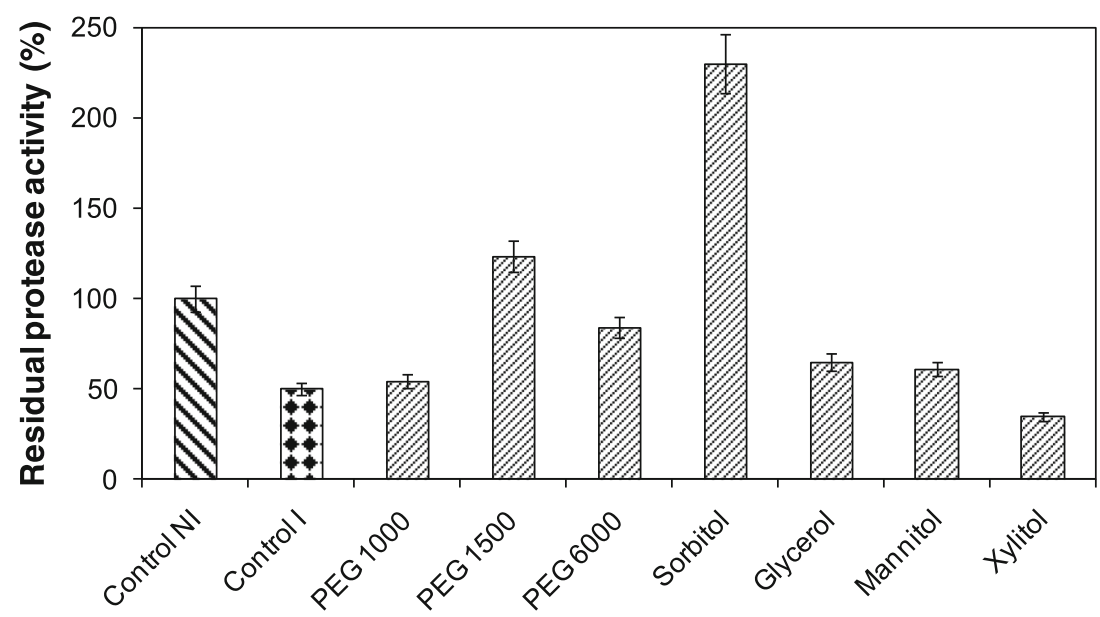

b

Polyol (100 mg/mL)

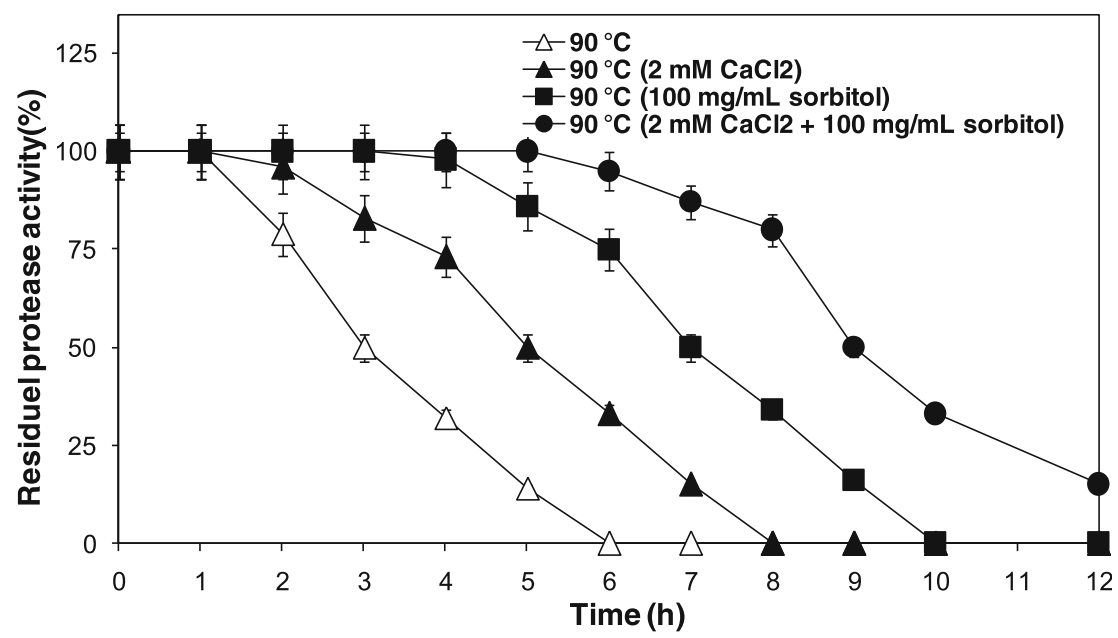

C

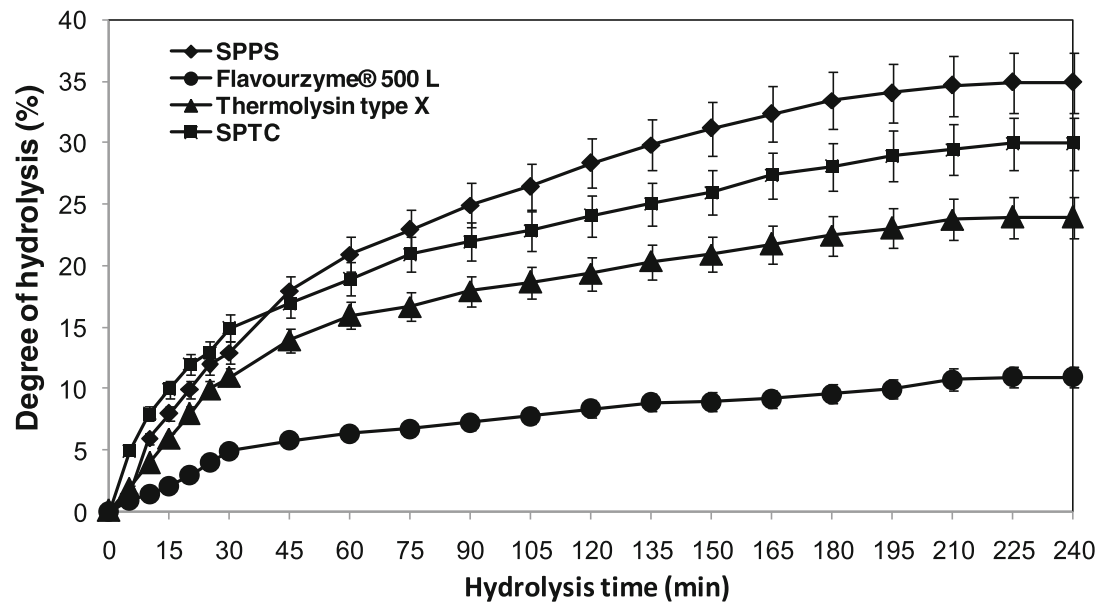

Fig. 4 a Effect of polyols on protease SPPS stability. $\mathbf{b}$ The combined effect of $\mathrm{Ca}^{2+}$ and sorbitol $10 \%(\mathrm{v} / \mathrm{v})$ on protease SPPS stability at $90^{\circ} \mathrm{C}$. $\mathbf{c}$ Hydrolysis curves of casein protein treated with various purified enzymes. The purified proteases used were: SPPS ( $\downarrow)$, SPTC ( $\mathbf{\bullet})$, Flavourzyme ${ }^{\circledR} 500$ $L(\bullet)$, and Thermolysin type $X(\mathbf{\Delta})$ 
literature. The purified SPPS was noted to exhibit esterase and amidase activities on BTEE and ATEE, but not on TAME, BAEE, and BCEE. It also displayed a preference for aromatic and hydrophobic amino-acid residues, such as Ala, Phe, Met, Leu, and Tyr and the carboxyl side of the splitting point in the P1 position (Table 4). This indicates that the SPPS enzyme acts on hydrophobic amino-acid residues attached to the carboxyl side of the cleavage sites of the chromogenic substrate. These characteristics, were in line with the other previously depicted subtilisins from bacterial $[28,32]$ and fungal $[26,33,41,42]$ origins. This indicated that the SPPS protease was slightly similar to subtilisins, not only in terms of specificity for position P1, but also with regard to the effects of amino-acids residues related to the cleavage site of the enzyme.

\section{Determination of kinetic parameters}

The kinetic parameters determined from LineweaverBurk plots are shown in Table 5 for SPPS, SPTC, Flavourzyme $500 \mathrm{~L}$, and Thermolysin type $\mathrm{X}$ purified enzymes using casein as substrate. The four used enzymes exhibited the classical kinetics of Michaelis-Menten. The returns indicate that the $K_{m}$ and $V_{\max }$ parameters for the SPPS enzyme, measured with casein, were 0.295 $\mathrm{mg} / \mathrm{mL}$ and $79,000 \mu \mathrm{mol} / \mathrm{mg} \cdot \mathrm{min}^{-1}$. The deduced catalytic efficiency $\left(k_{\mathrm{cat}} / K_{\mathrm{m}}\right)$ of the SPPS enzyme is 1.45 , 3.33, and 8.48 times compared to SPTC; Flavourzyme $500 \mathrm{~L}$, and Thermolysin type X, respectively.

The protease from Pleurotus sajor-caju strain CTM10057 displayed a $K_{m}$ value $(0.275 \mathrm{mg} / \mathrm{mL})$.

\section{Performance evaluation of the purified SPPS, SPTC, Flavourzyme ${ }^{\circledast} 500 \mathrm{~L}$, and Thermolysin type $\mathrm{X}$ enzymes Determination of hydrolysis degree}

Enzymatically hydrolyzed proteins possess functional properties, such as low viscosity, increased whipping ability, and high solubility, which make them favorable for food industry uses [43]. The hydrolysis degree of SPPS is achieved in curves of casein protein, after $240 \mathrm{~min}$ of incubation are shown in Fig. 4c. The purified enzymes were used at the same levels of activity for the production of protein hydrolysates from casein and for the subsequent comparisons of hydrolytic efficiencies. As shown in Fig. 4c, the purified SPPS was the most efficient, with $35 \%$ protease used during hydrolysis, followed by SPTC (30\%) and Thermolysin type X (24\%) with Flavourzyme $500 \mathrm{~L}$ being the least efficient (11\%) one.

These findings indicate that SPPS enzyme can be usefully employed for the preparation of protein hydrolysates.
Effects of organic-solvents on protease activity and stability of SPPS and Thermolysin type $X$

The effects of various organic solvents (at $50 \% \mathrm{v} / \mathrm{v}$, with different $\log \mathrm{P}_{\mathrm{ow}}$ ) on the stability of the purified SPPS and Thermolysin type $\mathrm{X}$ enzymes were determined by measuring residual activity under the optimum condition of each used enzyme after $72 \mathrm{~h}$ of incubation at $37^{\circ} \mathrm{C}$ (Fig. 5a). When it is compared to Thermolysin type X, SPPS is stable in both hydrophobe and hydrophile organic solvents. It was also noted to be more stable and tolerant in the presence of the acetonitrile. The SPPS protease has then an elevated tolerance to organic solvents, whatever their hydrophobicity is. It can be used yet in homogeneous and heterogeneous catalysis. It was well informative that enzyme deactivation can be assigned to the change of medium hydrophobicity [44]. Logically, polar solvent can penetrate into protein and changing structural for the interaction between the active site and substrate than non polar solvents. Thus, SPPS can be active in aqueous and non aqueous solutions. Accordingly, SPPS can be a potential candidacy for future application as a biocatalyst for the synthesis of peptide reactions in low water activity systems.

\section{Stability and compatibility of SPPS and Flavourzyme $e^{\circledast} 500 \mathrm{~L}$ with laundry detergents}

Recent researches have aimed at finding a substitute for the costly toxic chemicals by bio-products. Correspondingly, the use of proteases in the detergent field provides environmental and energetic advantages. In terms of energy, proteases use consists in washing at lower temperatures $\left(10-20^{\circ} \mathrm{C}\right)$. Moreover, the environmental benefit of such proteases incorporates less chemical surfactants use in order to preserve the environment. However, the desired detergent protease must be very active and stable in alkaline solution with respect to detergents [2]. This experience explores the application of SPPS protease in detergent industry. The data presented in Fig. 5b show that, compared to Flavourzyme $500 \mathrm{~L}$, SPPS was extremely stable and compatible with the commercial liquid detergents used, retaining $100 \%$ of its initial activity with Dixan, Nadhif, Detch, and Class detergents at a concentration of $7 \mathrm{mg} / \mathrm{mL}$ vs $100 \%$ of the initial activity of Flavourzyme $500 \mathrm{~L}$ with OMO, Ariel, and Det.

These results can approve the usefulness of SPPS as a cleaning bio-additive in detergent formulations used.

\section{Cleaning potential of detergent additive SPPS to remove the blood strain from cotton fabrics}

Alkaline serine proteases are usually sought in detergence industry [45]. They highly increase the cleaning efficacy of laundry detergent. Accordingly, a comparative test using Flavourzyme $500 \mathrm{~L}$ in Dixan was carried out (Fig. 5c). In fact, the blood strain was completely 
Table 4 Substrate specificity profile of SPPS enzyme from Pleurotus sajor-caju strain CTM10057

\begin{tabular}{|c|c|c|c|c|c|}
\hline \multicolumn{3}{|l|}{ Substrate } & \multirow{2}{*}{$\begin{array}{l}\text { Concentration } \\
30 \mathrm{~g} / \mathrm{L}\end{array}$} & \multirow{2}{*}{$\frac{{\text { Absorbance }(\mathrm{nm})^{\mathrm{a}}}_{660}}{6}$} & \multirow{2}{*}{$\begin{array}{l}\text { Relative protease activity (\%) } \\
100 \pm 2.5\end{array}$} \\
\hline \multirow[t]{5}{*}{ Natural protein } & \multicolumn{2}{|l|}{ Casein } & & & \\
\hline & \multicolumn{2}{|c|}{ Gelatin } & $30 \mathrm{~g} / \mathrm{L}$ & 660 & $80 \pm 2.0$ \\
\hline & \multicolumn{2}{|c|}{ Keratin } & $30 \mathrm{~g} / \mathrm{L}$ & 660 & $37 \pm 0.9$ \\
\hline & \multicolumn{2}{|c|}{ Ovalbumin } & $30 \mathrm{~g} / \mathrm{L}$ & 660 & $20 \pm 0.5$ \\
\hline & \multicolumn{2}{|l|}{ BSA } & $30 \mathrm{~g} / \mathrm{L}$ & 660 & $10 \pm 0.2$ \\
\hline \multirow[t]{5}{*}{ Modified protein } & \multicolumn{2}{|c|}{ Azo-casein } & $25 \mathrm{~g} / \mathrm{L}$ & 440 & $100 \pm 2.5$ \\
\hline & \multicolumn{2}{|c|}{ Albumin azure } & $25 \mathrm{~g} / \mathrm{L}$ & 440 & $50 \pm 1.8$ \\
\hline & \multicolumn{2}{|c|}{ Keratin azure } & $25 \mathrm{~g} / \mathrm{L}$ & 595 & $30 \pm 1.2$ \\
\hline & \multicolumn{2}{|c|}{ Collagen type I } & $20 \mathrm{~g} / \mathrm{L}$ & 440 & $0 \pm 0.0$ \\
\hline & \multicolumn{2}{|c|}{ Collagen type ॥ } & $20 \mathrm{~g} / \mathrm{L}$ & 440 & $0 \pm 0.0$ \\
\hline \multirow[t]{5}{*}{ Ester } & \multicolumn{2}{|l|}{ ATEE } & $10 \mathrm{mM}$ & 253 & $100 \pm 2.5$ \\
\hline & \multicolumn{2}{|l|}{ BTEE } & $10 \mathrm{mM}$ & 253 & $96 \pm 2.4$ \\
\hline & \multicolumn{2}{|l|}{ BAEE } & $10 \mathrm{mM}$ & 253 & $0 \pm 0.0$ \\
\hline & \multicolumn{2}{|l|}{ BCEE } & $10 \mathrm{mM}$ & 253 & $0 \pm 0.0$ \\
\hline & TAME & $\downarrow$ & $10 \mathrm{mM}$ & 253 & $0 \pm 0.0$ \\
\hline \multirow[t]{20}{*}{ Synthetic peptide (pNA) } & & Suc-F-pNA & $5 \mathrm{mM}$ & 410 & $49 \pm 1.5$ \\
\hline & & Benz-Y-pNA & $5 \mathrm{mM}$ & 410 & $0 \pm 0.0$ \\
\hline & & $M-p N A$ & $5 \mathrm{mM}$ & 410 & $0 \pm 0.0$ \\
\hline & & $A c-L-p N A$ & $5 \mathrm{mM}$ & 410 & $0 \pm 0.0$ \\
\hline & & $P-p N A$ & $5 \mathrm{mM}$ & 410 & $0 \pm 0.0$ \\
\hline & & $V-p N A$ & $5 \mathrm{mM}$ & 410 & $0 \pm 0.0$ \\
\hline & & $A c-A-p N A$ & $5 \mathrm{mM}$ & 410 & $62 \pm 1.6$ \\
\hline & & Benz-R-pNA & $5 \mathrm{mM}$ & 410 & $0 \pm 0.0$ \\
\hline & & Suc-YLV-pNA & $5 \mathrm{mM}$ & 410 & $0 \pm 0.0$ \\
\hline & & Suc-AAA-pNA & $5 \mathrm{mM}$ & 410 & $50 \pm 1.3$ \\
\hline & & Suc-AAV-pNA & $5 \mathrm{mM}$ & 410 & $64 \pm 1.7$ \\
\hline & & Suc-AAF-pNA & $5 \mathrm{mM}$ & 410 & $62 \pm 1.6$ \\
\hline & & Benz-FVR-pNA & $5 \mathrm{mM}$ & 410 & $0 \pm 0.0$ \\
\hline & & Suc-FAAF-pNA & $5 \mathrm{mM}$ & 410 & $100 \pm 2.5$ \\
\hline & & Suc-AAPF-pNA & $5 \mathrm{mM}$ & 410 & $97 \pm 2.5$ \\
\hline & & Suc-AAVA-pNA & $5 \mathrm{mM}$ & 410 & $92 \pm 2.4$ \\
\hline & & Suc-AAPM-pNA & $5 \mathrm{mM}$ & 410 & $77 \pm 1.9$ \\
\hline & & Suc-AAPL-pNA & $5 \mathrm{mM}$ & 410 & $65 \pm 1.7$ \\
\hline & & Suc-LLVY-pNA & $5 \mathrm{mM}$ & 410 & $57 \pm 1.6$ \\
\hline & & Ac-YVAD-pNA & $5 \mathrm{mM}$ & 410 & $0 \pm 0.0$ \\
\hline
\end{tabular}

\footnotetext{
a Values represent means of three independent replicates, and \pm standard errors are reported

${ }^{\mathrm{b}}$ The activity of each substrate was determined by measuring absorbance at specified wave lengths according to the relative method reported elsewhere [33, 34] BTEE, $N$-benzol-L-tyrosine ethyl ester; ATEE, $N$-acetyl-L-tyrosine ethyl ester monohydrate; BAEE, $N$-benzol-L-arginine ethyl ester; BCEE, S-benzyl-L-cysteine ethyl ester hydrochloride; TAME, $N_{\mathrm{a}}$ - -tosyl- L-arginine methyl ester hydrochloride; $N$-succinyl-F- $p$-nitroanilide; $N$-benzoyl-Y- $p$-nitroanilide; $M$ - $p$-nitroanilide; $N$-acetyl-L- $p$ nitroanilide; P- $p$-nitroanilide trifluoroacetate salt; $V$ - $p$-nitroanilide hydrochloride; $N$-acetyl-A- $p$-nitroanilide; $N$-benzoyl-R- $p$-nitroanilide; $N$-succinyl-YLV- $p$-nitroanilide; $N$-succinyl-AAA- $p$-nitroanilide; $N$-succinyl-AAF- $p$-nitroanilide; $N$-succinyl-AAV- $p$-nitroanilide; $N$-benzoyl-FVR- $p$-nitroanilide; $N$-succinyl-FAAF- $p$-nitroanilide; $N$-succinylAAPF- $p$-nitroanilide; $N$-succinyl-AAVA- $p$-nitroanilide; $N$-succinyl-AAPM- $p$-nitroanilide; $N$-succinyl-AAPL- $p$-nitroanilide; $N$-succinyl-LLVY- $p$-nitroanilide; and $N$-acetyl-YVAD-p-nitroanilide
}

removed. It is noted that SPPS isolated from Pleurotus sajor-caju strain CTM10057 is more efficient than Flavourzyme $500 \mathrm{~L}$ in Dixan. Thus, SPPS can be considered as a remarkable bio-additive in Dixan.

\section{Discussion}

This study is concerned with the production, purification and characterization of a new serine fungi protease. This protease is produced by Pleurotus sajor-caju strain 
Table 5 Kinetic parameters of the purified proteases: SPPS, SPTC, Flavourzyme ${ }^{\circledR} 500 \mathrm{~L}$, and Thermolysin type X for hydrolysis of natural protein (casein)

\begin{tabular}{|c|c|c|c|c|c|}
\hline Enzyme & Origin & $K_{m}(\mathrm{mg} / \mathrm{mL})^{a}$ & $V_{\max }\left(\mu \mathrm{mol} / \mathrm{mg} \cdot \mathrm{min}^{-1}\right)^{\mathrm{a}}$ & $k_{\text {cat }}\left(\min ^{-1}\right)$ & $k_{\text {cat }} / K_{m}\left(\mathrm{~mL} \cdot \mathrm{mg}^{-1} \cdot \mathrm{min}^{-1}\right)$ \\
\hline SPPS & Pleurotus sajor-caju CTM 10057 & $0.275 \pm 0.01$ & $79,000 \pm 695$ & 52,667 & 191,516 \\
\hline SPTC & Trametes cingulata CTM10101 & $0.475 \pm 0.02$ & $94,075 \pm 856$ & 62,717 & 132,036 \\
\hline Flavourzyme $^{\circledast} 500 \mathrm{~L}$ & Aspergillus oryzea & $0.546 \pm 0.04$ & $47,125 \pm 566$ & 31,417 & 57,540 \\
\hline Thermolysin type $X$ & Geobacillus stearothermophilus & $0.613 \pm 0.05$ & $20,764 \pm 323$ & 13,843 & 22,582 \\
\hline
\end{tabular}

${ }^{a}$ Values represent means of three independent replicates, and \pm standard errors are reported

CTM10057. The purification procedure strated by heat treatment $\left(80^{\circ} \mathrm{C}\right.$ for $\left.20 \mathrm{~min}\right)$ followed by ammonium sulfate precipitation (35-55\%)-dialysis, then UNO Q-6 FPLC ion-exchange chromatography and finally HPLCZORBAX PSM 300 HPSEC gel filtration chromatography. SPPS contained about $15 \%$ of the total activity of the crude and had a specific activity of $79,000 \mathrm{U} / \mathrm{mg}$ (Table 1) using casein as substrate. This specific activity is higher than Aspergillus oryzae strain $\mathrm{CH} 93(15,86 \mathrm{U} /$ mg) [14] and Aspergillus clavatus strain ES1 (37,600 U/ mg) [25]. According to native and SDS page study, SPPS was a homogeneous enzyme with high purity as it exhibits a unique elution symmetrical peak at retention time $\left(R_{t}\right)=11.6 \mathrm{~min}$ corresponding to a single protein of nearly $65 \mathrm{kDa}$ by HPLC gel filtration chromatography (Fig. 2b). This molecular weight was higher compared to those previously mentioned with respect to other fungal proteases like Pleurotus sajor-caju (48 kDa) [39]; Pleurotus citrinopileatus (28 kDa) [46]; Aspergillus clavatus ES1 (30 kDa) [25], and Aspergillus oryzae CH93 (47.5 $\mathrm{kDa}$ [14]. Moreover, the electrophoretic analyses and size exclusion chromatography showed that SPPS is a monomer comparable to the other previously reported fungi proteases $[25,26,33,39]$. These results strongly suggested that SPPS enzyme from strain CTM10057 was a novel protease. The highest homology was noted with the protease isolated from Pleurotus genus (90\%). SPPS belongs to the serine protease family according to the inhibitory test in bibliography, $22 \%$ of basidiomycete's protease belongs to serine protease [19]. Besides, this protease's class is widespread in eukaryotes microorganisms [13]. This enzyme is totally activated by $\mathrm{Ca}^{2+}$, $\mathrm{Mg}^{2+}$, and $\mathrm{Fe}^{2+}$, however, strongly inhibited by $\mathrm{Cd}^{2+}$, $\mathrm{Ni}^{2+}$, and $\mathrm{Hg}^{2+}(2 \mathrm{mM})$. This is similar to other serine proteases such as ES1 [25], SAPB [32], serine protease isolated from Pleurotus sajor-caju increased by $\mathrm{Ca}^{2+}$ and $\mathrm{Mg}^{2+}$ [39], protease isolated from Aspergillus oryzae strain $\mathrm{CH} 93$ and protease isolated from Aspergillus tamari strain URM 4634 [47]. Serine proteases are used to incorporate two calcium binding sites $[34,48]$ and their addition increase thermostability. It plays an important role in maintaining their 3D structure. In fact, $\mathrm{Ca}^{2+}$ was previously reported to improve serine protease activity and stability [32]. These ions can preserve the active confirmation at higher temperature [49]. This kind of protease (serine protease) is well known in the field of detergency. Insensitivity to chelators would be a valuable property for potential application in detergent formulations since these agents are added to soften water and remove stain [6]. The SPPS activity was totally inhibited by mercury ions, which could be ascribed to the exert toxicity of these ions, especially towards thiol serine protease $[50,51]$.

SPPS is an alkaline protease stable in alkaline solution. This propriety is also searched in protease and used as bio-additive in the detergent preparation. Proteolysis enzymes with appropriate specificity and stability to temperature and $\mathrm{pH}$ are necessary for the physiology of ligninolytic fungi [52]. The thermo-stability of SPPS in very high temperature is a substantial feature preferred in proteases used as bio-additive in laundry detergent [9]. Extremely high temperature can destabilize the noncovalent interactions of protein $[8,53]$. It has further been suggested that the protective role of polyols is ascribed to their capability to form hydrogen bonds that support and stabilize the native conformation of the enzyme to make it more resistant to heat treatment. The impact of polyols on protease activity is well studied. Other researchers have also shown the improvement of thermostability of proteases in the presence of polyols $[28,54]$. The protective impact of polyols is dispersed based on these latter's hydroxyl groups belonging. The addition of some polyols is pivotal in order to maintain hydrophobic interactions within protein molecules. It has further been suggested that the protective role of polyols is assigned to their capability to form hydrogen bonds that support and stabilize the native conformation of the enzyme to make it more resistant to heat treatment.

The stability of microbial proteases by polyols has been broadly depicted by several works, such as SPACG from Caldicoprobacter guelmensis strain $\mathrm{D} 2 \mathrm{C} 22^{\mathrm{T}}$ [54], and SAPHM from Bacillus licheniformis strain K7A [33]. The highest activity on protein was noted with casein, followed by gelatin, and albumin azure. Other serine proteases such as BAP from Beauveria sp. strain MTCC 5184 possess the same substrate specificity. It was more active against casein compared to hemoglobin and 

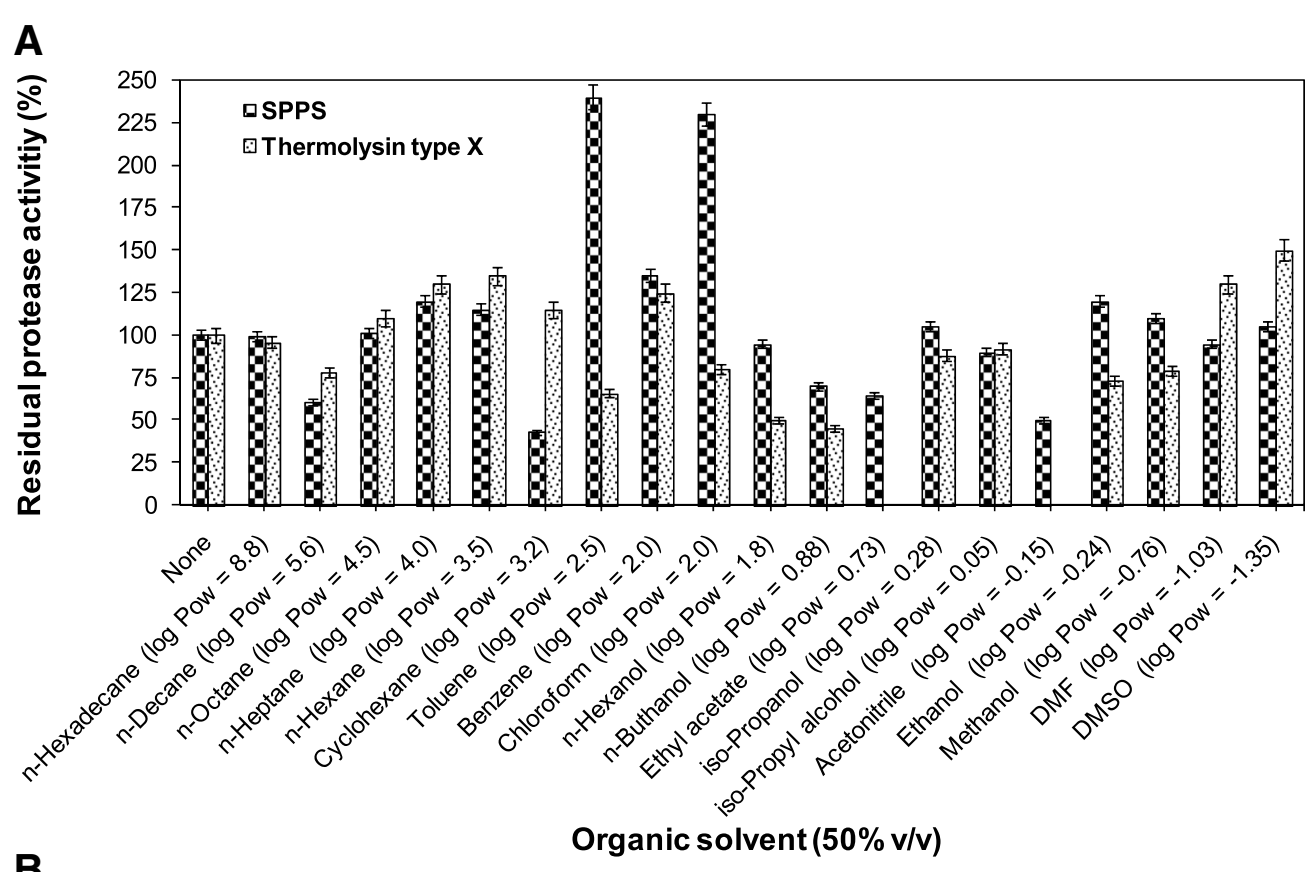

B

Organic solvent $(50 \% \mathrm{v} / \mathrm{v})$

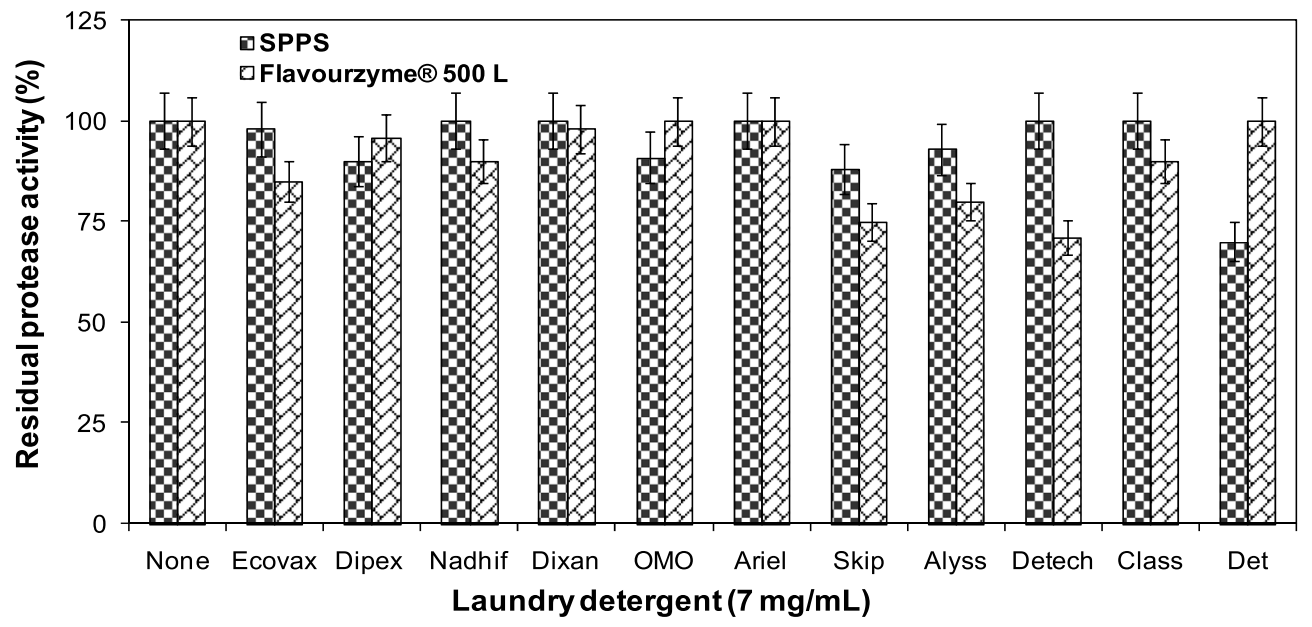

C

b
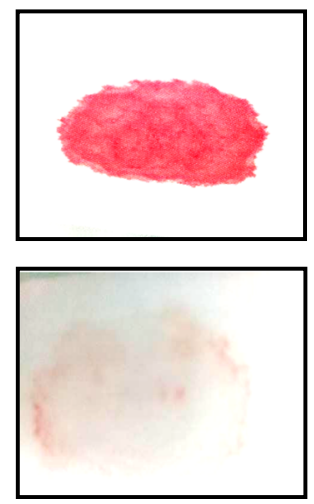

C
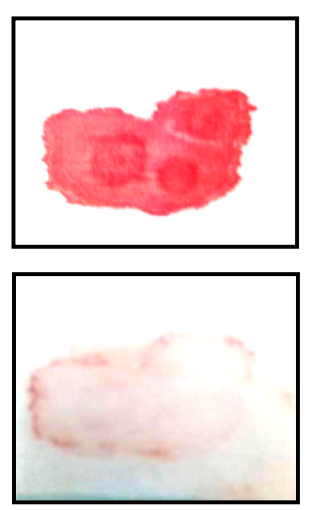

d
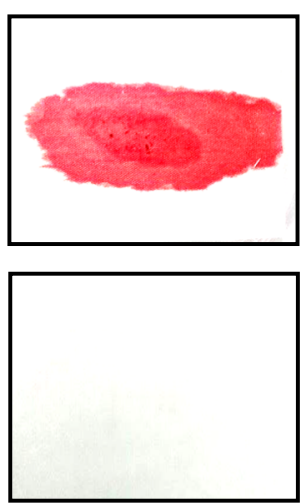

Fig. 5 (See legend on next page.) 
(See figure on previous page.)

Fig. 5 A Effect of different organic solvent on SPPS and Thermolysin type X enzyme stabilities; B Stability of SPPS and Flavourzyme $500 \mathrm{~L}$ purified proteases in the presence of commercial liquid [Nadhif from Henkel-Alki (Tunisia), Ariel from Procter \& Gamble (Switzerland), Skip from Unilever (France), Class from EJM (Tunisia), and Dipex from Klin Productions (Tunisia)] and solid [Dixan from Henkel (France), Ecovax from Klin Productions (Tunisia), OMO from Unilever (France), Alyss from EJM (Tunisia), Detech from SOTUP (Tunisia), and Det from Sodet (Tunisia)] laundry detergents at $7 \mathrm{mg} / \mathrm{mL}$. Enzyme activity of the control sample, which contained no additive and incubated under similar conditions, was taken as $100 \%$. Vertical bars indicate standard error of the mean $(n=3)$. C Washing performance analysis test of SPPS enzyme in the presence of the commercial detergent Dixan. Cloth stained with blood washed with: (a) tap water, (b) Dixan detergent (7 mg/mL), (c) Dixan added with Flavourzyme $500 \mathrm{~L}$ (commercial enzyme, $500 \mathrm{U} / \mathrm{mL}$ ), and (d) Dixan added with SPPS (500 U/mL). I: untreated cloths (control) and II: treated cloths

bovine serum albumin [51]. This specificity of cleavage to natural protein has already been elaborated in other proteases from fungi. The substrate specificity profile of SPPS indicates that it is subtilisin-like. However, the enzyme activity of protease produced by Aspergillus flavus strain AP2 was the highest with gelatin [55]. The protease from Pleurotus sajor-caju strain CTM10057 has a less $K_{m}$ value $(0.275 \mathrm{mg} / \mathrm{mL})$ as proteases isolated from Pleurotus citrinopileatus $(3.44 \mathrm{mg} / \mathrm{mL})$ [46], Amanita virgineoides $(3.74 \mathrm{mg} / \mathrm{mL})$ [56], and Helvella lacunose $(3.81 \mathrm{mg} / \mathrm{mL})$ [57], i.e. SPPS protease evinced a higher affinity towards casein than the above-mentioned proteases. Nevertheless, SPPS has a $K_{m}$ value $(0.275 \mathrm{mg} / \mathrm{mL})$ comparable with the protease isolated from Mucor bacilliformis $\left(K_{m}=0.185 \mathrm{mg} / \mathrm{mL}\right)$ [58] and Cordyceps sobolifera $(0.41 \mathrm{mg} / \mathrm{mL})$ [59], which means similar affinities towards casein possessed three fungal proteases. Hopefully, future works can find out the position of substrate binding site and modify it to enhance the substrate affinity. Thereby, the presence of some organic solvents altering the structure-function of many proteins [60]. As well detailed, the proteases produced by Pseudomonas aeruginosa PseA and PST-01 have a high stability and tolerance toward hydrophobic and hydrophilic solvents, respectively [61]. However, Jaouadi et al. reported that AMPP protease produced by Pseudomonas aeruginosa CTM50182 displayed high stability in the presence of various organic solvents than commercial enzymes [62]. On the other hand, $n$-butanol showed strong inhibition in protease activity from Aspergillus niger WA 2017 [63]. Thus, the intrinsic organic solvent-tolerance and stability of some enzymes depends on the nature of the used organic solvents, which makes them highly attractive to industry $[64,65]$.

Owing to its stability towards detergency compositions, SPPS can be used in detergent formulations as a cleaning bio-additive. A similar work has shown the stability and compatibility of the protease from Aspergillus terreus gr. in the presence of some comment ingredient bleach-based detergent formulation [16], showing that it is appropriate candidate for cleaning power of laundry detergent compositions [66] . The alkaline protease isolated from Pleurotus sajor-caju CTM10057 was completely stable in the presence of various detergent additives than Flavourzyme ${ }^{\circ}$
$500 \mathrm{~L}$. Similar studies have revealed that alkaline proteases produced by Bacillus licheniformis [33], Aspergillus terreus [16], and Aspergillus niger [67] demonstrated good stability in commercial laundry detergents. In alkaline condition, the stability of the protease SPPS indicates a significant enzyme compatibility with laundry detergent and, therefore, making it a potential candidate for use in detergent formulations as cleaning additive that facilitates proteinaceous stains release.

\section{Conclusions}

Accordingly, a novel fungal protease with a great industrial interest, from Pleurotus sajor-caju CTM 10057 was purified to homogeneity and biochemically characterized. Therefore, this mushroom constitutes a new source of proteolytic activity for future applications. Compared to SPTC and commercial proteases Flavourzyme ${ }^{\circ} 500 \mathrm{~L}$ and Thermolysin type X, SPPS showed high hydrolysis degree and catalytic efficiency. Besides, compared to Thermolysin type $\mathrm{X}$ and Flavourzyme $500 \mathrm{~L}$, SPPS displayed significant tolerance in the presence of some organic solvents, as well as an excellent stability and compatibility with a wide range of commercialized laundry detergents, respectively. Thus, SPPS offers new and promising opportunities for industrial and biotechnological perspective bioprocess, mainly in peptides synthesis and detergent formulation. Further and supplementary works are needed to isolate the spPS encoding gene, to hyperproduce the recombinant enzyme (rSPPS) in heterologous-expression system and to explore its structure-function relationships using site-directed mutagenesis approach and 3D structure modeling.

\section{Abbreviations}

ATEE : N-acetyl-L-tyrosine ethyl ester monohydrate; BAEE: N-benzyol-Larginine ethyl ester; BCEE: S-benzyl-L-cysteine ethyl ester hydrochloride; BSA: Bovine serum albumin; BTEE: N-benzol-L-tyrosine ethyl ester; DFP: Diiodopropyl fluorophosphate; DMC: $N, N$-dimethylated casein; DTNB: 5,5'-dithio-bis-2-nitro benzoic acid; EPNP: 1.2-epoxy-3-(pnitrophenoloxy) propane; FPLC: Fast protein liquid chromatography; HPLC: High performance liquid chromatography; iodoacetamide: $\beta-M E, \beta-$ mercaptoethanol; LD-DTT: LD-dithiothreitol; MIA: Monoiodoacetic acid; NEM: N-ethylmalemide; PAGE: Polyacrylamide gel electrophoresis; PCR: Polymerase chain reaction; PDB: Potato dextrose broth; PEG: Propylene glycol; PMSF: Phenylmethyl sulfonyfluoride; rDNA: ribosomal DNA; SBTI: Soybean trypsin inhibitor; SDS: Soduim dodecyl sulphate; SPPS: Serine alkaline protease from Pleurotus sajor-caju strain CTM10057; TAME: $N_{a}-p$-tosylL-arginine methyl ester hydrochloride; TLCK: Na-p-tosyl-L-lysine chloromethyl ketone; TPCK: Na-p-tosyl-L-phenylalanine chloromethyl ketone 


\section{Acknowledgments}

The authors would like to express their gratitude to Mr. K. Walha, Mrs. N. Kchaou, and Mrs. N. Masmoudi (Analysis Unit-CBS) for their technical assistance with the HPLC and FPLC and Pr. H. Mejdoub and Mr. C. Bouzid (USCR/ SP, FSS, University of Sfax) for the $\mathrm{NH}_{2}$-terminal amino-acid sequencing of the SPPS protein. We extend our thanks to Dr. W. Saibi and Pr. H. Belghith (CBS) for their constructive discussions and suggestions and Mrs. S. Kchaou (CTM Unit-CBS) for the gift of the filamentous fungi strain CTM10057. Special thanks are also due to Pr. W. Hariz from the English Department at the FSS, University of Sfax (Sfax, Tunisia) for constructively proofreading and language polishing services. This work is part of a Doctoral Thesis in Chemical-Process Engineering by Miss Maroua OMRANE BENMRAD at the National Engineering School of Gabes (ENIG) at the University of Gabes (Gabes, Tunisia).

\section{Authors' contributions}

BJ: Study design as well as experiments collection, analysis, and interpretation; MOB, SM, NZJ, HR, and MBE: Performing experiments; MOB, SM, NZJ, MBE, and HR: Data analysis and interpretation; MOB and SM: Manuscript writing; BJ, NK, SS, and SB: Manuscript revision and editing. All authors read and approved the final manuscript.

\section{Funding}

This study was supported by the Tunisian Ministry of Higher Education and Scientific Research under the Contract Program (Grant n:. LMBEE_CBS/code: LR15CBS06_2015-2019). The funding entity had no contribution in the study design and data collection, analysis, and interpretation as well as the manuscript writing.

\section{Availability of data and materials}

The datasets generated and/or analyzed during the current study are available on the GenBank repository, https://www.ncbi.nlm.nih.gov/genbank/. The GenBank accession number for the nucleotide sequence of the $18 \mathrm{~S}$ rDNA gene referred to in the text is MH806376. Other datasets generated during and/or analyzed during the current study available from the corresponding author on reasonable request.

\section{Ethics approval and consent to participate}

Not applicable.

\section{Consent for publication}

Not applicable.

\section{Competing interests}

The authors declare that they have no competing interests.

\begin{abstract}
Author details
'Laboratory of Microbial Biotechnology and Engineering Enzymes (LMBEE), Centre of Biotechnology of Sfax (CBS), University of Sfax, Road of Sidi Mansour Km 6, P.O. Box 1177, 3018 Sfax, Tunisia. ${ }^{2}$ Biotech ECOZYM Start-up, Business Incubator, Centre of Biotechnology of Sfax (CBS), University of Sfax, Road of Sidi Mansour Km 6, P.O. Box 1177, 3018 Sfax, Tunisia. ${ }^{3}$ Laboratory of Environmental Bioprocesses (LEBP), LMI COSYS-Med, Centre of Biotechnology of Sfax (CBS), University of Sfax, Road of Sidi Mansour Km 6, P.O. Box 1177, 3018 Sfax, Tunisia. ${ }^{4}$ Research Group of Agro-Food Processing Engineering (GP2A), Laboratory of Applied Fluid Mechanics, Process Engineering and Environment, National School of Engineers of Sfax (ENIS), University of Sfax, Road of Soukra Km 4, P.O. Box 1173, 3038 Sfax, Tunisia.
\end{abstract}

Received: 17 September 2018 Accepted: 17 June 2019

Published online: 01 July 2019

\section{References}

1. Inácio FD, Ferreira RO, Araujo CAVd, Brugnari T, Castoldi R, Peralta RM, Souza CGMd. Proteases of wood rot fungi with emphasis on the genus Pleurotus. BioMed Res Int. 2015;290161:1-10. http://dx.doi.org/10.1155/2015/290161.

2. Hirata A, Hori Y, Koga Y, Okada J, Sakudo A, Ikuta K, Kanaya S, Takano K. Enzymatic activity of a subtilisin homolog, Tk-SP, from Thermococcus kodakarensis in detergents and its ability to degrade the abnormal prion protein. BMC Biotechnol. 2013;13(1):19.

3. Singh R, Kumar M, Mittal A, Mehta PK. Microbial enzymes: industria progress in 21st century. 3 Biotech. 2016;6(2):174
4. Kudryavtseva O, Dunaevsky YE, Kamzolkina O, Belozersky M. Fungal proteolytic enzymes: features of the extracellular proteases of xylotrophic basidiomycetes. Microbiology. 2008;77(6):643-53.

5. Yin C, Zheng L, Chen L, Tan Q, Shang X, Ma A. Cloning, expression, and characterization of a milk-clotting aspartic protease gene (Po-Asp) from Pleurotus ostreatus. Appl Biochem Biotechnol. 2014;172(4):2119-31.

6. Gupta R, Beg Q, Lorenz P. Bacterial alkaline proteases: molecular approaches and industrial applications. Appl Microbiol Biotechnol. 2002;59(1):15-32.

7. Kulkarni N, Shendye A, Rao M. Molecular and biotechnological aspects of xylanases. FEMS Microbiol Rev. 1999;23(4):411-56.

8. Li Q, Yi L, Marek P, Iverson BL. Commercial proteases: present and future. FEBS Lett. 2013;587(8):1155-63.

9. PMd S, MLdA B, Caprara CC, Md F, RPCd A, Silveira D, Fonseca YM, Ferreira Filho EX, Pessoa Junior A, Magalhães PO. A biotechnology perspective of fungal proteases. Braz J Microbiol. 2015;46(2):337-46.

10. Baweja M, Singh PK, Sadaf A, Tiwari R, Nain L, Khare SK, Shukla P. Cost effective characterization process and molecular dynamic simulation of detergent compatible alkaline protease from Bacillus pumilus strain MP27. Process Biochem. 2017;58:199-203.

11. Olsen HS, Falholt $P$. The role of enzymes in modern detergency. J Surfactant Deterg. 1998;1(4):555-67.

12. Zhao HY, Feng $H$. Engineering Bacillus pumilus alkaline serine protease to increase its low-temperature proteolytic activity by directed evolution. BMC Biotechnol. 2018;18(1):34.

13. Mienda B, Yahya A, Galadima I, Shamsir M. An overview of microbial proteases for industrial applications. Res J Pharm Biol Chem Sci. 2014;5(1):388-96.

14. Salihi A, Asoodeh A, Aliabadian M. Production and biochemical characterization of an alkaline protease from Aspergillus oryzae CH93. Int J Biol Macromol. 2017;94:827-35.

15. Sharma KM, Kumar R, Panwar S, Kumar A. Microbial alkaline proteases: optimization of production parameters and their properties. J Genet Eng Biotechnol. 2017:15(1):115-26.

16. Niyonzima FN, More SS. Purification and characterization of detergentcompatible protease from Aspergillus terreus gr. 3. Biotech. 2015;5(1):61-70.

17. Haddar A, Bougatef A, Agrebi R, Sellami-Kamoun A, Nasri M. A novel surfactant-stable alkaline serine-protease from a newly isolated Bacillus mojavensis A21. Purification and characterization. Process Biochem. 2009; 44(1):29-35.

18. Mechri S, Kriaa M, Ben Elhoul Berrouina M, Omrane Benmrad M, Zaraî Jaouadi N, Rekik H, Bouacem K, Bouanane-Darenfed A, Chebbi A, Sayadi S. Optimized production and characterization of a detergent-stable protease from Lysinibacillus fusiformis C250R. Int J Biol Macromol. 2017;101:383-97.

19. Sabotič J, Trček T, Popovič T, Brzin J. Basidiomycetes harbour a hidden treasure of proteolytic diversity. J Biotechnol. 2007;128(2):297-307.

20. Jalomo-Khayrova E, Mares RE, Munoz PLA, Melendez-Lopez SG, Rivero IA, Ramos MA. Soluble expression of an amebic cysteine protease in the cytoplasm of Escherichia coli SHuffle express cells and purification of active enzyme. BMC Biotechnol. 2018;18(1):20.

21. Li Y, Pan $Y$, She $Q$, Chen $L$. A novel carboxyl-terminal protease derived from Paenibacillus lautus CHN26 exhibiting high activities at multiple sites of substrates. BMC Biotechnol. 2013;13:89.

22. Breene WM. Nutritional and medicinal value of specialty mushrooms. J Food Protect. 1990;53:883-94.

23. Choi JH, Kim DW, Kim S, Kim SJ. Purification and partial characterization of a fibrinolytic enzyme from the fruiting body of the medicinal and edible mushroom Pleurotus ferulae. Prep Biochem Biotechnol. 2017;47(6):539-46.

24. Palmieri G, Bianco C, Cennamo G, Giardina P, Marino G, Monti M, Sannia G. Purification, characterization, and functional role of a novel extracellular protease from Pleurotus ostreatus. Appl Environ Microbiol. 2001;67(6):2754-9.

25. Hajji M, Kanoun S, Nasri M, Gharsallah N. Purification and characterization of an alkaline serine-protease produced by a new isolated Aspergillus clavatus ES1. Process Biochem. 2007:42(5):791-7.

26. Omrane Benmrad M, Moujehed E, Ben Elhoul M, Zaraî Jaouadi N, Mechri S, Rekik H, Kourdali S, El Hattab M, Badis A, Sayadi S, Bejar S, Jaouadi B. A novel organic solvent- and detergent-stable serine alkaline protease from Trametes cingulata strain CTM10101. Int J Biol Macromol. 2016;91:961-72.

27. Li F. Wen ha, Liu X, Zhou F, Chen G. gene cloning and recombinant expression of a novel fungal immunomodulatory protein from Trametes versicolor. Protein Expres Purif. 2012;82(2):339-44.

28. Mechri S, Ben Elhoul Berrouina M, Omrane Benmrad M, Zaraî Jaouadi N, Rekik H, Moujehed E, Chebbi A, Sayadi S, Chamkha M, Bejar S, Jaouadi B. 
Characterization of a novel protease from Aeribacillus pallidus strain VP3 with potential biotechnological interest. Int J Biol Macromol. 2017;94(Part A): 221-32.

29. Boulkour Touioui S, Zaraî Jaouadi N, Boudjella H, Ferradji FZ, Belhoul M, Rekik $\mathrm{H}$, Badis A, Bejar S, Jaouadi B. Purification and biochemical characterization of two detergent-stable serine alkaline proteases from Streptomyces sp. strain AH4. World J Microbiol Biotechnol. 2015;31(7):1079-92.

30. Bradford MM. A rapid and sensitive method for the quantitation of microgram quantities of protein utilizing the principle of protein-dye binding. Anal Biochem. 1976;72(1-2):248-54.

31. Laemmli UK. Cleavage of structural proteins during the assembly of the head of bacteriophage T4. Nature. 1970;227(5259):680-5.

32. Jaouadi B, Ellouz-Chaabouni S, Rhimi M, Bejar S. Biochemical and molecular characterization of a detergent-stable serine alkaline protease from Bacillus pumilus CBS with high catalytic efficiency. Biochimie. 2008;90(9):1291-305.

33. Hadjidj R, Badis A, Mechri S, Eddouaouda K, Khelouia L, Annane R, El Hattab $\mathrm{M}$, Jaouadi B. Purification, biochemical, and molecular characterization of novel protease from Bacillus licheniformis strain K7A. Int J Biol Macromol. 2018;114:1033-48

34. Zaraî Jaouadi N, Rekik H, Badis A, Trabelsi S, Belhoul M, Yahiaoui AB, Ben Aicha H, Toumi A, Bejar S, Jaouadi B. Biochemical and molecular characterization of a serine keratinase from Brevibacillus brevis US575 with promising keratin-biodegradation and hide-dehairing activities. PLoS One. 2013;8(10):e76722

35. Adler-Nissen J. Enzymic hydrolysis of food proteins. London: Elsevier Applied Science Publishers Ltd.; 1986.

36. Frost DV, Heinsen J. Determination of the degree of hydrolysis of partial acid hydrolysates of casein and fibrin. J Biol Chem. 1945;161(2):517-21.

37. Zaraî Jaouadi N, Jaouadi B, Aghajari N, Bejar S. The overexpression of the SAPB of Bacillus pumilus CBS and mutated sapB-L311/T33S/N99Y alkaline proteases in Bacillus subtilis DB430: new attractive properties for the mutant enzyme. Bioresour Technol. 2012;105:142-51.

38. Colja L, Sjef B, Kees V, Cees V. Rules for optimization of biocatalysis in organic solvents. Biotechnol Bioeng. 1987;30(1):81-7.

39. Ravikumar G, Gomathi D, Kalaiselvi M, Uma C. A protease from the medicinal mushroom Pleurotus sajor-caju: production, purification and partial characterization. Asian Pac J Trop Biomed. 2012;2(1):S411-7.

40. Steuer $\mathrm{C}$, Heinonen $\mathrm{KH}$, Kattner L, Klein CD. Optimization of assay conditions for dengue virus protease: effect of various polyols and nonionic detergents. J Biomol Screen. 2009;14(9):1102-8.

41. Omrane Benmrad M, Moujehed E, Ben Elhoul M, Mechri S, Bejar S, Zouari R, Baffoun A, Jaouadi B. Production, purification, and biochemical characterization of serine alkaline protease from Penicillium chrysogenium strain X5 used as excellent bio-additive for textile processing. Int J Biol Macromol. 2018;119:1002-16.

42. Deng Y, Liu X, Katrolia P, Kopparapu NK, Zheng X. A dual-function chymotrypsin-like serine protease with plasminogen activation and fibrinolytic activities from the GRAS fungus, Neurospora sitophila. Int J Biol Macromol. 2018;109:1338-43.

43. Adler-Nissen J. Determination of the degree of hydrolysis of food protein hydrolysates by trinitrobenzenesulfonic acid. J Agric Food Chem. 1979;27(6): 1256-62.

44. Annamalai N, Rajeswari MV, Sahu SK, Balasubramanian T. Purification and characterization of solvent stable, alkaline protease from Bacillus firmus CAS 7 by microbial conversion of marine wastes and molecular mechanism underlying solvent stability. Process Biochem. 2014;49(6):1012-9.

45. Coral G, Arikan B, Unaldi M, Guvenmez H. Thermostable alkaline protease produced by an Aspergillus niger strain. Ann Microbiol. 2003;53(4):491-8.

46. Cui L, Liu Q, Wang H, Ng T. An alkaline protease from fresh fruiting bodies of the edible mushroom Pleurotus citrinopileatus. Appl Microbiol Biotechnol. 2007;75(1):81-5.

47. da Silva OS, de Almeida EM, de Melo AHF, Porto TS. Purification and characterization of a novel extracellular serine-protease with collagenolytic activity from Aspergillus tamarii URM4634. Int J Biol Macromol. 2018;117: 1081-8.

48. Ben Elhoul M, Zaraî Jaouadi N, Rekik H, Omrane Benmrad M, Mechri S, Moujehed E, Kourdali S, El Hattab M, Badis A, Bejar S. Biochemical and molecular characterization of new keratinoytic protease from Actinomadura viridilutea DZ50. Int J Biol Macromol. 2016;92:299-315.

49. Kumar CG, Takagi H. Microbial alkaline proteases: from a bioindustrial viewpoint. Biotechno Adv. 1999;17(7):561-94.
50. Ben Elhoul M, Zaraî Jaouadi N, Rekik H, Bejar W, Boulkour Touioui S, Hmidi M, Badis A, Bejar S, Jaouadi B. A novel detergent-stable solvent-tolerant serine thiol alkaline protease from Streptomyces koyangensis TN650. Int J Biol Macromol. 2015:79:871-82.

51. Shankar S, Rao M, Laxman RS. Purification and characterization of an alkaline protease by a new strain of Beauveria sp. Process Biochem. 2011;46(2):579-85.

52. Datta A. Purification and characterization of a novel protease from solid substrate cultures of Phanerochaete chrysosporium. J Biol Chem. 1992;267(2): 728-32.

53. Dill KA. Dominant forces in protein folding. Biochemistry. 1990;29(31):7133-55.

54. Bouacem K, Bouanane-Darenfed A, Laribi-Habchi H, Elhoul MB, Hmida-Sayari A, Hacene H, Ollivier B, Fardeau ML, Jaouadi B, Bejar S. Biochemical characterization of a detergent-stable serine alkaline protease from Caldicoprobacter guelmensis. Int J Biol Macromol. 2015;81:299-307.

55. Hossain M, Das F, Marzan L, Rahman MS, Anwar M. Some properties of protease of the fungal strain Aspergillus flavus. Int J Agric Biol. 2006;8:162-4.

56. Yuan X, Zhu M, Tian G, Zhao Y, Zhao L, Ng TB, Wang H. Biochemical characteristics of a novel protease from the basidiomycete Amanita virgineoides. Biotechnol Appl Biochem. 2017:64(4):532-40.

57. Zhang G, Wang $\mathrm{H}$, Zhang $X, \mathrm{Ng}$ T. Helvellisin, a novel alkaline protease from the wild ascomycete mushroom Helvella lacunosa. J Biosci Bioeng. 2010; 109(1):20-4.

58. Venera GD, Machalinski C, Zum'arraga H, Biscoglio MJ. de Bonino je. Further characterization and kinetic parameter determination of a milk-clotting protease from Mucor bacilliformis. Appl Biochem Biotechnol. 1997;68(3):207-16.

59. Wang SX, Liu Y, Zhang GQ, Zhao S, Xu F, Geng XL, Wang HX. Cordysobin, a novel alkaline serine protease with HIV-1 reverse transcriptase inhibitory activity from the medicinal mushroom Cordyceps sobolifera. J Biosci Bioeng. 2012;113(1):42-7.

60. Barberis S, Quiroga E, Morcelle S, Priolo N, Luco JM. Study of phytoproteases stability in aqueous-organic biphasic systems using linear free energy relationships. J Mol Catal B-Enzy. 2006;38(2):95-103.

61. Ogino H, Watanabe F, Yamada M, Nakagawa S, Hirose T, Noguchi A, Yasuda M, Ishikawa H. Purification and characterization of organic solvent-stable protease from organic solvent-tolerant Pseudomonas aeruginosa PST-01. J Biosci Bioeng. 1999;87(1):61-8.

62. Jaouadi B, Zaraî Jaouadi N, Rekik H, Naili B, Beji A, Dhouib A, Bejar S. Biochemical and molecular characterization of Pseudomonas aeruginosa CTM50182 organic solvent-stable elastase. Int J Biol Macromol. 2013;60:165-77.

63. Abdel Wahab WA, Ahmed SA. Response surface methodology for production, characterization and application of solvent, salt and alkalitolerant alkaline protease from isolated fungal strain Aspergillus niger WA 2017. Inter J Biol Macromol. 2018;115:447-58.

64. Barberis S, Quiroga E. Arribére MaC, Priolo N. peptide synthesis in aqueousorganic biphasic systems catalyzed by a protease isolated from Morrenia brachystephana (Asclepiadaceae). J Mol Catal B- Enzy. 2002;17(1):39-47.

65. Ogino H, Uchiho T, Doukyu N, Yasuda M, Ishimi K, Ishikawa H. Effect of exchange of amino acid residues of the surface region of the PST-01 protease on its organic solvent-stability. Biochem Biophys Res Commun. 2007:358(4):1028-33.

66. Beena A, Geevarghese P, Jayavardanan K. Detergent potential of a spoilage protease enzyme liberated by a psychrotrophic spore former isolated from sterilized skim milk. Am J Food Technol. 2012;7(2):89-95.

67. Devi MK, Banu AR, Gnanaprabha G, Pradeep B, Palaniswamy M. Purification, characterization of alkaline protease enzyme from native isolate Aspergillus niger and its compatibility with commercial detergents. Indian J Sci Technol. 2008;1(7):1-6.

\section{Publisher's Note}

Springer Nature remains neutral with regard to jurisdictional claims in published maps and institutional affiliations. 